Aksaray University

Journal of Science and Engineering

e-ISSN: 2587-1277

http://dergipark.gov.tr/asujse

http://asujse.aksaray.edu.tr
UN/

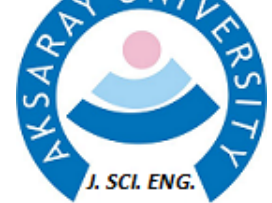

J. SCI. ENG.
Aksaray J. Sci. Eng.

Volume 2, Issue 2, pp. 95-115

doi: 10.29002/asujse. 331754

Available online at DergiPark

Research Article

\title{
Geological, Petrographical and Geochemical Properties of Pyroclastic Rocks in the Civanadag Region (Gugu-Balikesir), NW Turkey
}

\author{
Murat Kalkan ${ }^{1, *}$, Yahya Ozpinar ${ }^{2}$ \\ ${ }^{1}$ Aksaray University, Engineering Faculty, Department of Geological Engineering, Aksaray, 68100, Turkey \\ ${ }^{2}$ Pamukkale University, Engineering Faculty, Department of Geological Engineering, Denizli, 20017, Turkey
}

\begin{abstract}
The study area is located between Balikesir-Dursunbey and Kutahya-Simav districts. According to the field studies and petrographic studies on Civanadag tuffs, it is determined that this unit is formed by two different facies as Upper (fine-grained laminated facies) and Lower (pumice accumulation facies) facies. Lower facies begins with tuffs which are rich by pumice contains metamorphic gravel. Upper level of facies, size of pumice and lithic components decrease. The fine-grained laminated upper facies begins with pink-colored lithic-vitric tuff, vitric tuffs and whitish-gray lithic-vitric tuffs. The uppermost level is represented by abundant green coloured biotite crystal-vitric tuffs. Tuffs end with agglomerates. Pyrogen minerals determined in the petrographic investigations of Civanadag tuffs; quartz + sanidine +plagioclase +biotite \pm amphibole. Major, trace and rare earth element contents of Civanadag tuff, which is characterized by their rhyolite, dacite composition, calc-alkaline, show fractional crystallization process which is chiefly controlled by $\mathrm{K}$-feldspar and plagioclase. Also high $\mathrm{K}$ and $\mathrm{Rb}$ contents in the spider diagram indicate the presence of crustal contamination and magma mixing.
\end{abstract}

\section{Keywords}

Gugu, Civanadag tuffs, Petrography, Geochemistry

"Corresponding Author: Murat Kalkan, mkalkan@aksaray.edu.tr 


Aksaray University
Journal of Science and Engineering
e-ISSN: 2587-1277
http://dergipark.gov.tr/asujse
http://asujse.aksaray.edu.tr

Research Article

\title{
Civanadă̆ Bölgesi (Güğü-Balıkesir) Piroklastik Kayaçlarının Jeolojik, Petrografik ve Jeokimyasal Özellikleri, KB-Türkiye
}

\author{
Murat Kalkan ${ }^{1 *}$, Yahya Özpınar \\ ${ }^{1}$ Aksaray Üniversitesi, Mühendislik Fakültesi, Jeoloji Mühendisliği, Aksaray, 68100, Türkiye \\ ${ }^{2}$ Pamukkale Üniversitesi, Mühendislik Fakültesi, Jeoloji Mühendisliği, Denizli, 20017, Türkiye
}

-Gönderi Tarihi:30 Tem 2017

-Düzeltme Tarihi:29 Ara 2017

-Kabul Tarihi:06 Şubat 2018

-Çevrimiçi Yayın Tarih:12 Haz 2018

\section{Özet}

Çalışma alanı Balıkesir-Dursunbey ile Kütahya-Simav ilçeleri arasında yer almaktadır. Civanadağ tüfleri üzerinde yapılan arazi ve petrografik çalışmalara göre, birimin alt (pomza yı̆̆ışım fasiyesi) ve üst (ince taneli laminalı fasiyes) fasiyes olmak üzere iki farklı fasiyesten oluştuğu belirlenmiştir. Alt fasiyes, metamorfik çakıl içerikli pomzaca zengin tüfler ile başlamakta olup, üst seviyelerde pomza ve litik bileşen boyutu azalmaktadır. İnce taneli ve yer yer laminalanma gösteren üst fasiyes ise, pembe renkli, litik-vitrik tüf, vitrik tüfler ve beyazımsı gri renkli litik-vitrik tüfler ile başlamaktadır. Beyaz renkli kristal-vitrik tüf ve vitrik-kristal tüf ile devam etmektedir. En üst seviyesi ise, yeşil renkli bol biyotitli kristal-vitrik tüfler ile temsil edilmektedir. Tüfler, aglomeralar ile son bulmaktadır. Civanadağ tüflerinin petrografik incelemelerinde saptanan pirojen mineraller; kuvars +sanidin +plajioklas +biyotit \pm amfiboldür. Riyolit, dasit bileşimli kalkalkalen karakterli özelliğe sahip Civanadağ tüflerinin ana oksit, iz ve nadir toprak element içerikleri tüfün gelişiminde fraksiyonel kristallenmenin önemli bir rol oynadığını, bu kristallenmenin başlıca K-feldispat ve plajiyoklas tarafindan kontrol edildiğini göstermektedir. Ayrıca örümcek diyagramındaki yüksek K ve Rb içeriği, kabuk kirlenmesi ve magma karışımının varlığına işaret etmektedir.

\section{Anahtar Kelimeler}

Güğü, Civanadağ tüfleri, Petrografi, Jeokimya

*Sorumlu Yazar: Murat Kalkan, mkalkan@aksaray.edu.tr 


\section{GIRİŞ}

Batı Anadolu bölgesel ölçekte, kor kompleksin yükselmesine, normal fay sistemleri ve buna bağlı havzaların oluşmasına neden olan kabuksal gerilmenin, yaygın olarak temsil edildiği bir bölgedir. Batı Anadolu'da kuzey-güney, kuzeydoğu-güneybat1, kuzeybatı-güneydoğu (Gördes, Demirci, Selendi ve Uşak-Güre grabenleri) ve doğu-batı yönelimli (Edremit, Bakırçay, Simav, Gediz, Küçük Menderes ve Gökova grabenleri) iki büyük havza/graben sistemi bulunmaktadır [1-17]. Bu havza/graben sistemi üzerine çeşitli görüşler olmasına karşın bir görüşe göre, yaklaşık KD-GB uzanımlı havzalar, İzmir-Ankara sütur zonu boyunca Anatolid-Torid platformu ile Pontidler'in Geç Kretase-Eosen'deki çarpışmasını takip eden ve Orta Miyosen'e kadar devam eden sıkışma rejiminin ürünleri olup, daha sonra Tortoniyen ve daha genç D-B uzanımlı grabenler tarafından kesilmektedir [2-3, 10]. Diğer bir görüşe göre ise, K-G açılma rejiminin en geç Oligosen-Erken Miyosen'den itibaren var olduğunu ve hem kuzey hem de doğu-batı uzanımlı havzaların Erken Miyosen'den itibaren eş yaşlı olarak oluşmaya başladığını savunur [4-5, 7-8]. Her iki havzanın oluşumuna da yaygın bir biçimde magmatik ve bunlarla ilişkili volkanik faaliyetler eşlik etmiştir [8, 10]. Batı Anadolu'daki aynı sıkışma rejimi, kabuksal kısalma ve kalınlaşma [18] ile birlikte Oligosen-Miyosen döneminde magmatik faaliyetlere [19] ve Erken Miyosen'de geniş yayılımlı kalk-alkalin volkanik aktiviteye [20] neden olmuştur. Batı Anadolu'da oldukça geniş yüzleklere sahip olan Geç Senozoyik yaşlı volkanik kayaçlar, kimyasal özellikleri temelinde başlıca iki gruba ayrılmaktadır [21-22]. Ortaç-asidik bileşimli ve genelde kalk-alkali karaktere sahip olan volkanik ürünlerin; Geç Oligosen-Erken Miyosen yaş aralığında, Geç Miyosen'e kadar devam eden K-G yönlü sıkışma sonucu geliştiğini, bazaltik bileşimli ve başlıca alkali karaktere sahip olan volkanik ürünlerin Geç Miyosen-Pliyosen yaşlı, Geç Miyosen'den sonra ortaya çıkan K-G yönlü açılma rejimi altında oluştuğunu belirtmişlerdir [4, 10, 23-26]. Ancak açılma rejiminin Geç Oligosen sonundan itibaren geçerli olduğunu savunan çalışmacılar volkanik kayaçların bileşimindeki bu değişimin, astenosferin katkısındaki artma ve kabuksal kirlenme oranındaki azalma nedeniyle ortaya çıktığını savunmuşlardır [8].

İnceleme alanı D-B uzanımlı Kuvaterner yaşlı Simav grabenin kuzeyinde, KB-GD uzanımlı Bigadiç Borat havzasının doğusunda ve Alaçamdağ magmatik kompleksi içinde yer almaktadır. Bölgenin jeolojisine ait ilk bulgular [27] tarafindan ortaya konulmuştur. Bölgedeki diğer çalışmalar ise temel birimleri kesen Alaçam granitinin jeokimyası, mika yaşı ve granitin yerleşimine yönelik çalışmalardır [19, 28-30]. Bu çalışmanın amacı Alaçamdă̆ magmatik kompleksi içerisinde, bölgede geniş yüzlekler ve 350-400 metrelik kalın bir istif sunan 
Civanadağ tüflerinin litolojik özelliklerinin yardımıyla ölçüsüz stratigrafik istifinin ortaya konulması ve mineralojik, petrografik ve jeokimyasal özelliklerinin belirlenmesidir.

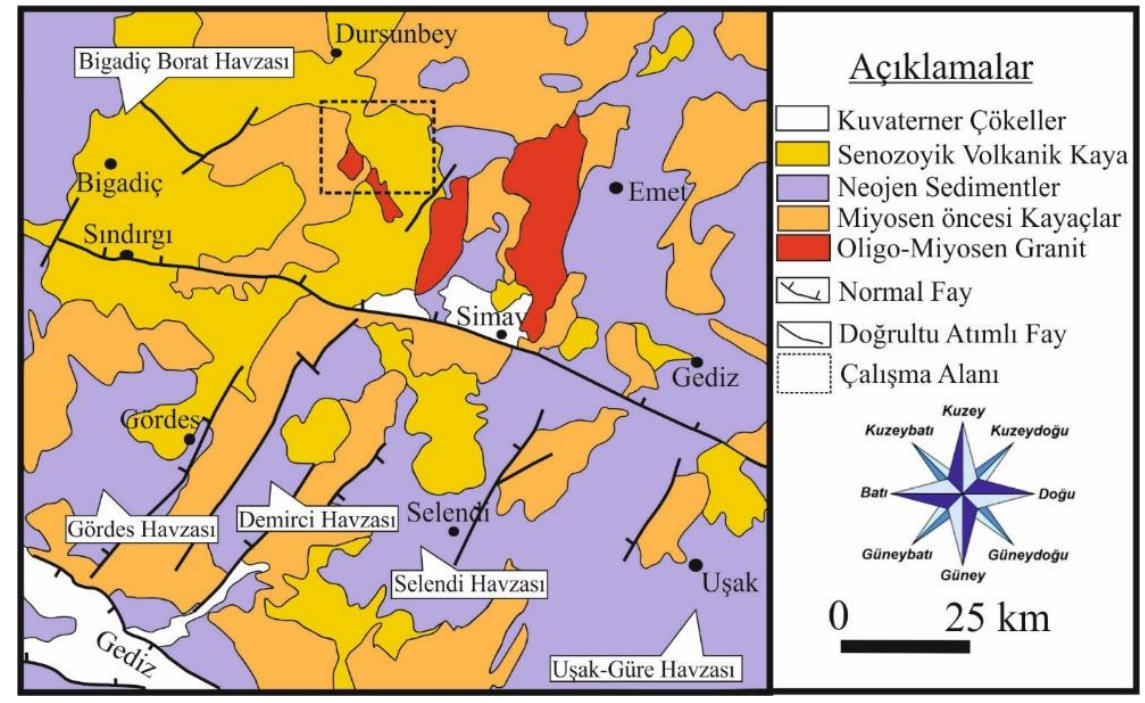

Şekil 1. Çalışma alanının bölgesel jeoloji haritası [31]

\section{MATERYAL VE YÖNTEM}

Çalışma kapsamında araziden derlenen 39 adet el örneğinin ince kesitleri hazırlanarak polarizan mikroskopta ayrıntılı olarak incelenmiştir. Bu örneklerin petrografik özellikleri belirlenmiştir. Arazi çalışmaları ve petrografik incelemeler esas alınarak ve mümkün olduğunca ayrışmamış olmasına özen gösterilerek seçilen 7 adet örnekten ana oksit, iz ve nadir toprak element analizleri yapılmıştır. Önce çeneli, daha sonra da halkalı öğütücüde yaklaşık 200 meshe kadar ögütülen örnekler ana oksit, iz ve nadir element analizi için ACME Analitk Laboratuvarlarına (Kanada)'na gönderilmiştir. Burada ana oksit ve iz elementler ICP (Inductively coupled plasma= İndüktif birleşik plazma), nadir toprak elementler ise ICP-MS (Inductively coupled plasma-mass spectrometer $=$ İndüktif birleşik plazma-kütle spektrometre) ile analiz edilmiştir.

\section{BULGULAR VE TARTIŞMA}

\subsection{Genel Jeoloji}

Çalışma alanın temelinde Paleozoyik yaşlı Menderes Masifine ait Simav Metamorfitleri ile üzerinde tektonik dokanaklı olarak Jura yaşlı Afyon-Ankara zonuna ait kırıntılı çökeller ve kireçtaşları ile temsil edilen Budağan kireçtaşları ve Kretase yaşlı metabazitler ve mermerler ile temsil edilen Dağardı melanjı yer almaktadır [27, 32]. Neojen öncesi bu birimler Erken Miyosen yaşlı Alaçam graniti ve mikrograniti tarafından kesilir. Alttaki tüm birimler üzerine açısal uyumsuzlukla, sarımsı kahverengi renkli kumtaşları ve çamur taşlarından temsil edilen Yeniköy Formasyonu gelmektedir. Yeniköy formasyonun üzerinde beyaz, gri, krem, yeşilimsi renklerde riyolit, riyodasit, ve dasit arasında değişen bileşime sahip tüflerden oluşan Civanadağ 
tüfleri yer almaktadır [27]. Bu tüflerin üzerinde açısal uyumsuzluk ile riyolit-dasit-andezit içerikli Akdağ volkanikleri bulunmaktadır (Şekil 2). En üstte de Toklargölü formasyonunun güncel tutturulmamış kaba kırıntılıları ve alüvyon ile son bulmaktadır (Şekil 3).

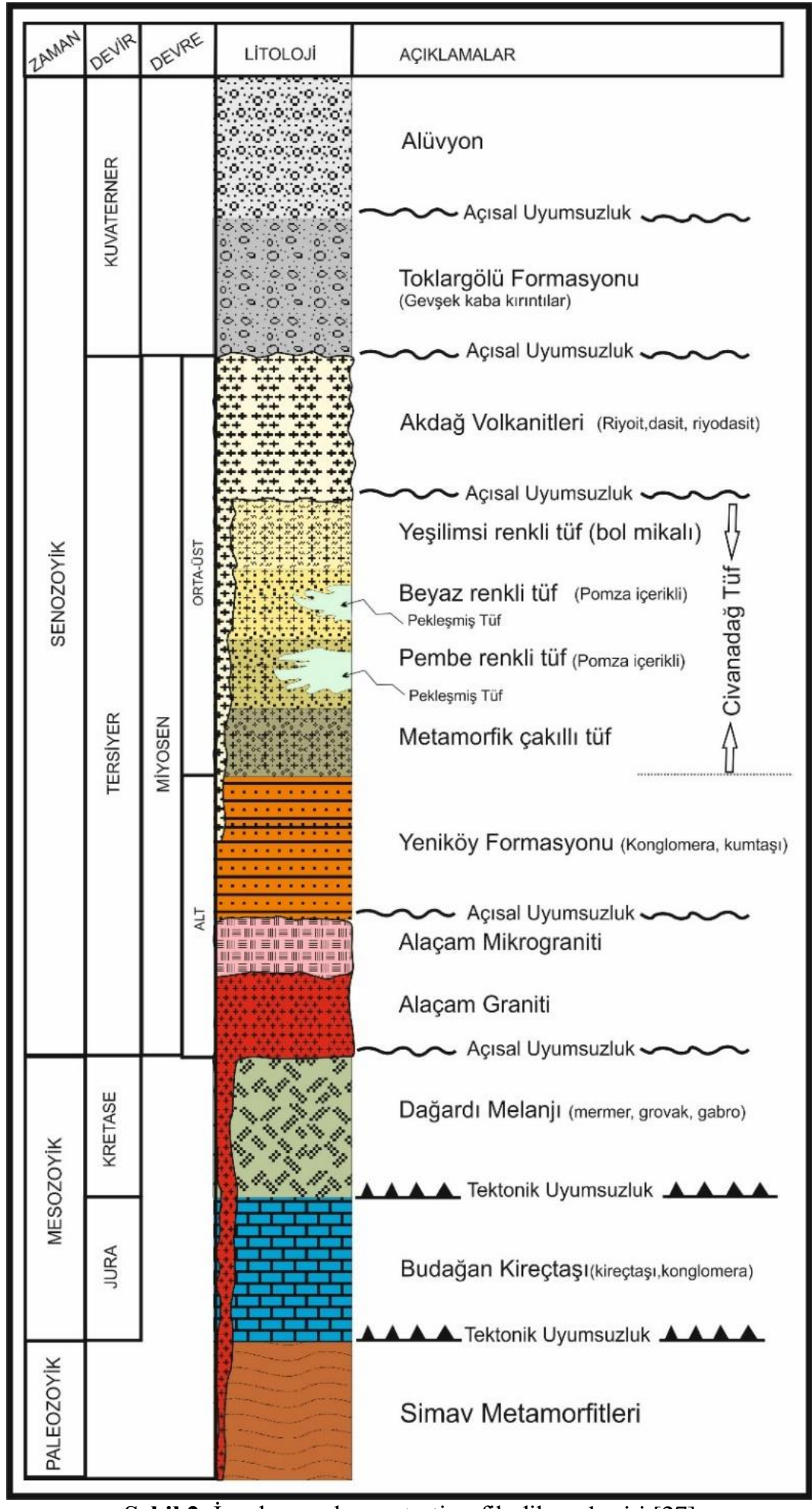

Şekil 2. İncelenen alanın stratigrafik dikme kesiti [27] 


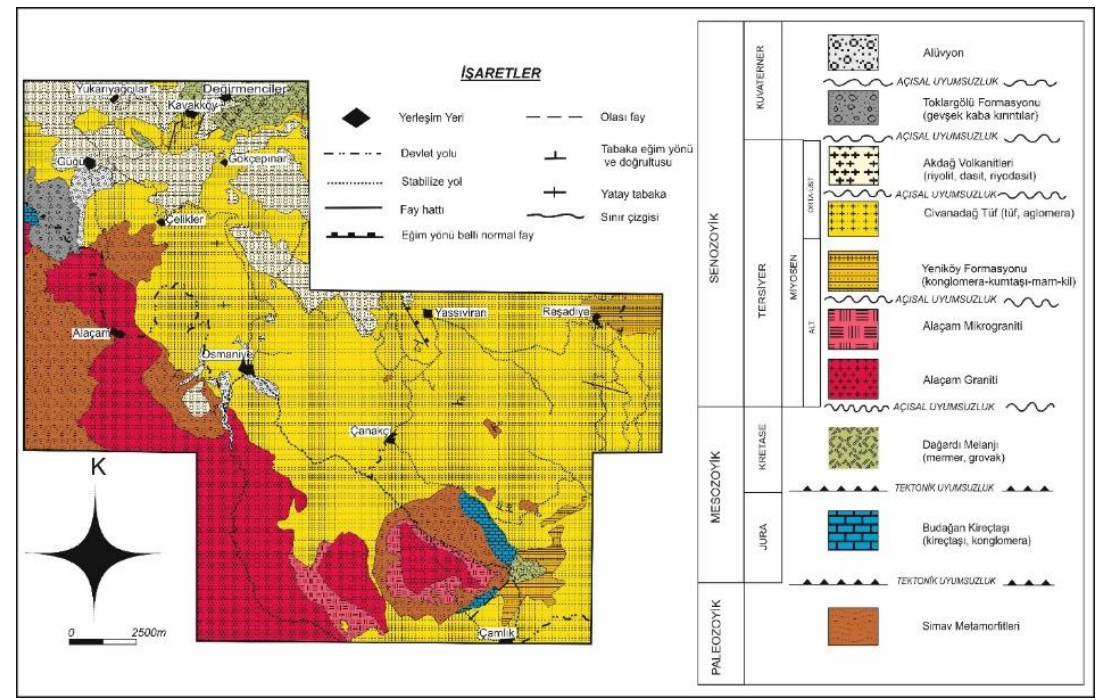

Şekil 3. Çalışma alanının jeoloji haritası

\subsection{Civanadağ Tüfleri}

Beyaz, gri, krem renkli başlica tüf ve aglomeralardan oluşan birim; Konak [32], tarafindan “Civanadağ Tüfleri” olarak tanımlanırken; Ercan ve ark. [33], tarafından ise tüm volkanitleri “'Karaboldere Volkanitleri’’ olarak adlandırmışlardır.

Çalışma alanın orta ve doğu kesimlerinde geniş yüzeylenmeler sunan tüfler, alanının yaklaşık yarısından fazlasını işgal etmektedir. Civanadağ tüfleri üzerinde ince ve detaylı çalışma yapılarak ölçeksiz stratigrafik istifi ortaya çıkarılmıştır. Piroklastik kayaçların altta pomzaca zengin olan fasiyes ile onun üzerinde ince taneli fasiyes ve en üsttede aglomeralardan oluştukları belirlenmiştir (Şekil 4). Ayırtlanan fasiyeslerin litolojik özellikleri aşağıda verilmektedir.

\subsubsection{Pomzaca zengin fasiyes}

Pomzaca zengin fasiyes; tüf istifinin tabanında, çalışılan alanın batı kesimlerinde yer almaktadır. Alt zonlarda litik bileşenlerin ve pomza tanelerinin boyutları daha büyüktür. Litik bileşen olarak çoğunlukla metamorfik kayaç parçaları içerdikleri görülmüştür (Şekil 5a). Metamorfik kaya parçaları mika şist ve kuvars şist türü kaya parçalarından oluşmaktadır. Pomzaca zengin olan fasiyes arazi de beyaz ve beyazımsı gri renklerde görülen yüzeylenmeler oluşturmaktadır (Şekil 5b). Pomzaca zengin fasiyesin üst zonlarında ise pomza tanelerinin boyutları küçülmüş olarak izlenir. Pomza tanelerinin dizilimleri ile oluşan yer yer ince tabakamsı seviyelerde gözlenmeye başlar (Şekil 5c). Daha üst seviyelere doğru düzensiz ve farklı boyutlu pomza yığışımları görülmekte ayrıca pomza tanelerinin ve ayrıca litik bileşenlerin de boyutlarında daha da küçülme ve azalma belirlenir (Şekil 5d). 
Altta yer alan Yeniköy Formasyonu ile geçişli olarak bulunur. Yer yer demirli alterasyon zonlarının yanında silisli zonlar ve kalın silis damarları içerirler.

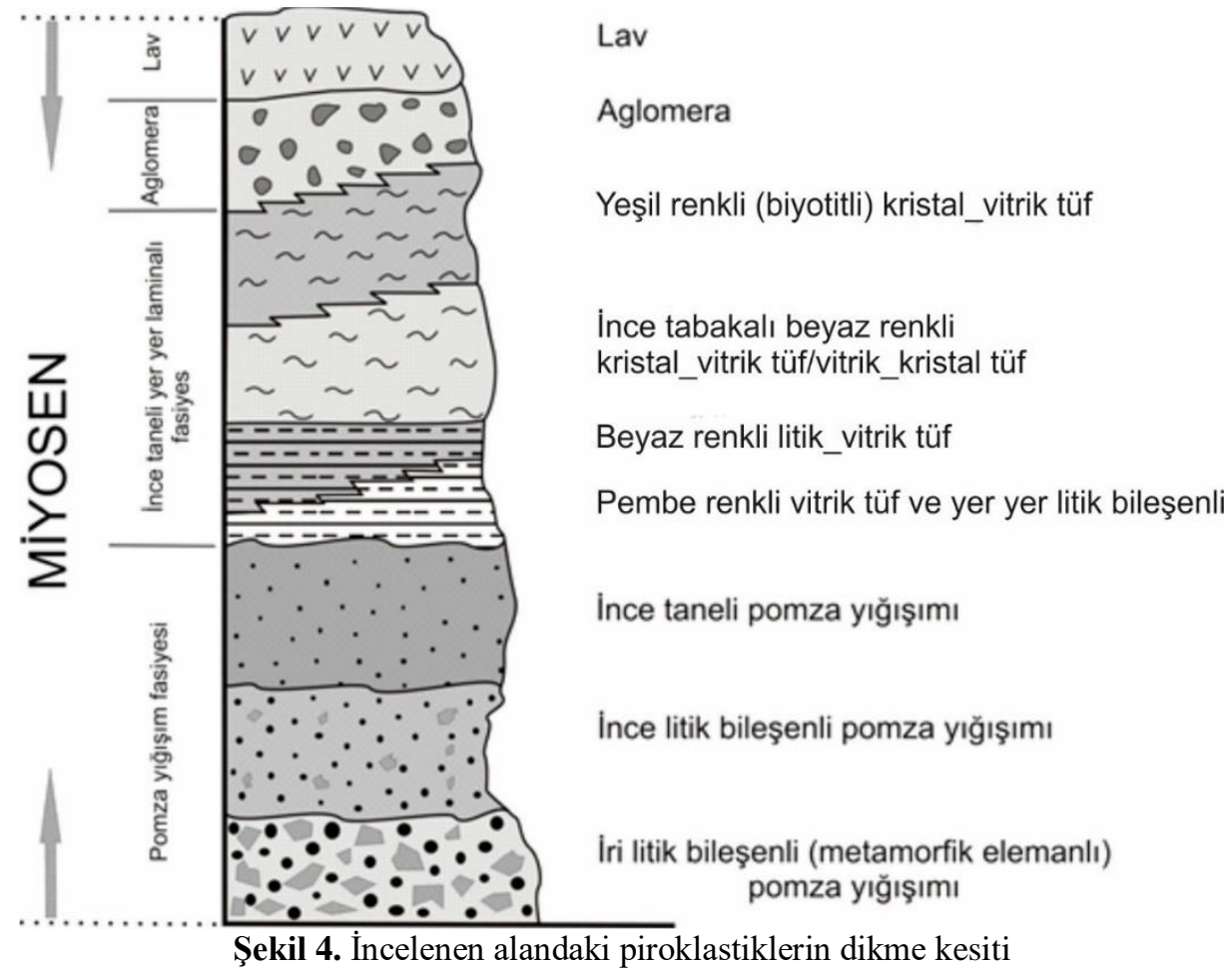

\subsubsection{Ince taneli ve yer laminalı fasiyes}

İnce taneli ve yer yer laminalanma gösteren fasiyes altta beyaz renkli fakat yer yer pembe seviyeler içeren tüfler ile başlamaktadır (Şekil 6a). Üst zonlarda ise biyotitli tüflerden oluşmaktadır. Yoğun biyotit içeren tüfler, arazide açık yeşil ve koyu yeşil renklerde izlenmişlerdir (Şekil 6b). İnce taneli fasiyes, yer yer kaynaklanmış olduğundan arazide belirgin olarak aşınması zor olan morfolojiler oluşturmuş ve çoğunlukla daha üst rakımlı alanlarda tespit edilmiştir. İnce taneli fasiyesteki renk değişimleri tüflerin mineral içerikleri ve/veya başka bir tanımla kristal yığışımlarındaki mineral içeriği ile ilgili olduğu anlaşılmaktadır. Örneğin, beyaz renkli olan tüflerde kuvars kristalleri egemen iken, yeşil renkli olan tüflerde ise, biyotit yığışımları ve biyotitlerin alterasyonu ile oluşan opak minerallerin egemen olduğu belirlenmiştir. İnce taneli fasiyesteki tüflerde, litik bileşen olmasına karşın çok küçük taneli ve daha az oranlarda olduğu görülmüştür. İnce taneli fasiyeste ayrıca fiamme yapılarıda tespit edilmiştir (Şekil 6c).

\subsubsection{Aglomera}

Piroklastik kayaların en üst fasiyesini oluşturur. Birimin tabanda ince taneli fasiyes ile geçişli durumda ve üstüne de lavlar gelmektedir. Fasiyes içindeki iri lav (aglomera) blokları $15 \mathrm{~cm}$ lik boyutlara ulaşmıştır. Taneler tüf ile bağlanmıştır (Şekil 6d). 

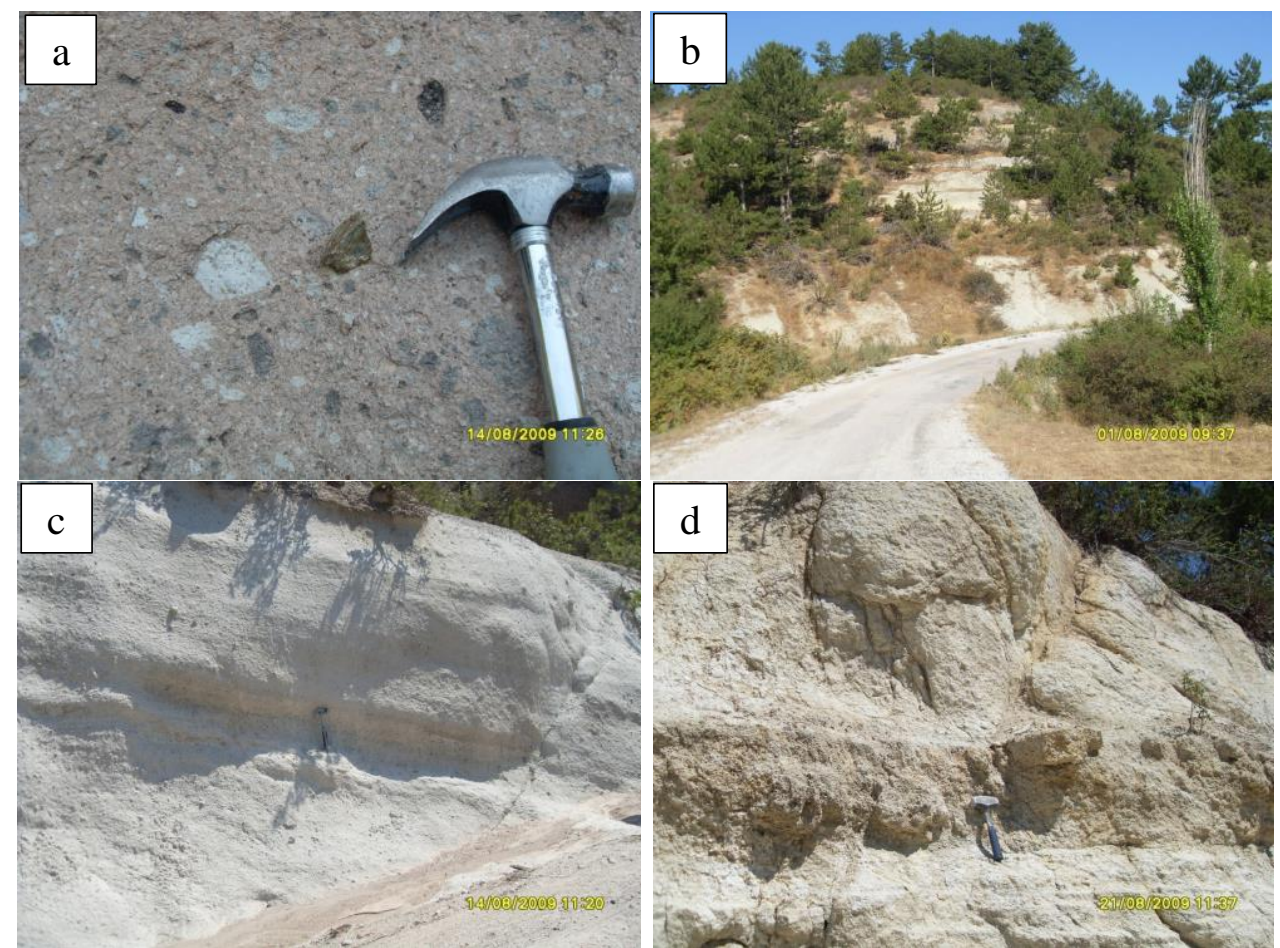

Şekil 5. a) En altta yer alan metamorfik kayaç (litik bileşen) çakılllı ve pomzalı fasiyesin görünümü (Çelikler köyü yolu doğusu, Kızılağaç Tepenin 50m doğusu). b) Pomzaca zengin fasiyes, üst düzeylerde beyaz ve beyazımsı renklerde kalın tabakalı bir görünüm sunmaktadır (Reşadiye köyü yolu yol kenarı, köye $250 \mathrm{~m}$ ). c) Pomzaca zengin fasiyeste düzenli pomza yığışımlarının görünümü (Çelikler köyü yolu doğusu, Kızılağaç Tepenin, 50m doğusu). d) Pomzaca zengin fasiyeste düzensiz ve farklı boyutlu pomza yı̆̆ı̧ımlarının görünümü (Çelikler köyü yolu, köyün $750 \mathrm{~m}$ güneybatıs1)
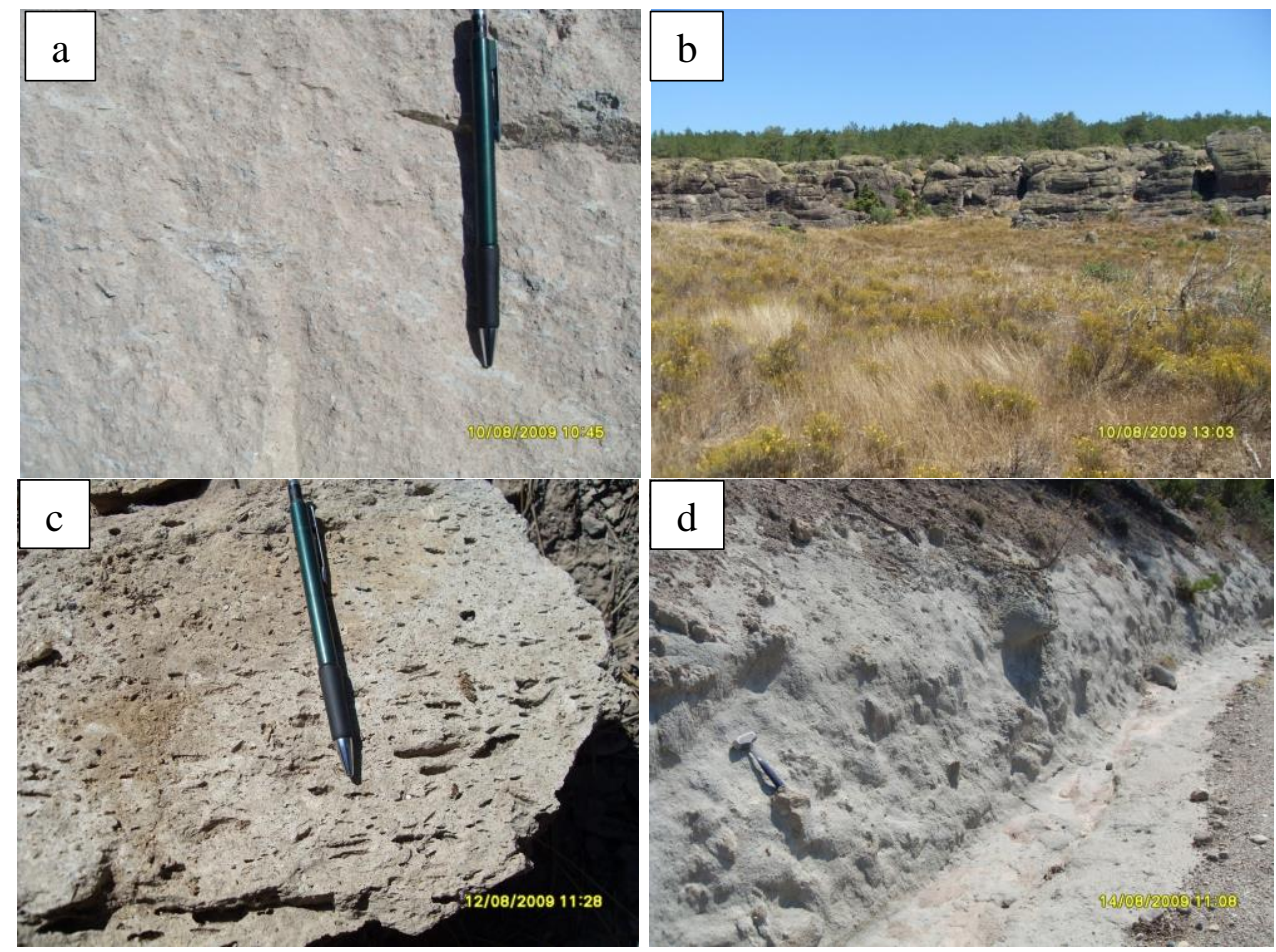

Şekil 6. a) Pomzaca zengin fasiyes üzerinde yer alan ince taneli fasiyeste kısmen kaynaklaşmış pembemsibeyazımsı tüf (Osmaniye köyünün $1 \mathrm{~km}$ kuzeyi yol kenarı). b) Pomzaca zengin fasiyes üzerinde kısmen kaynaklaşmış yeşilimsi tüf düzeyleri (Gökçepınar köyü güneydoğusu, Kayabaşı tepenin $250 \mathrm{~m}$ batısı). c) İnce taneli fasiyeste fiamme yapılarının görünümü (Osmaniye köyü kuzeydoğusu, Çevirmekaba Tepenin 250m kuzeydoğusu). d) Aglomera biriminin arazide görünümü (Gökçepınar köyünün $1 \mathrm{~km}$ güneydoğusu yol kenarı, Murtluçuk Tepenin 250m güneybatısi). 
Tablo 1. Tüf örneklerinin mikroskobik incelenmelerinde saptanan mineral bileşimleri

\begin{tabular}{|c|c|c|c|c|c|c|c|c|c|c|c|}
\hline Örnek & $\mathbf{Q}$ & San & PI & $\mathbf{B i}$ & Kal & Klst & Ser & Op. & $\mathbf{F e}$ & Litik Bileşen & Kayacın adı \\
\hline DUP-1 & + & + & - & + & + & - & + & - & + & - & Kristal-vitrik tüf \\
\hline DUP-3 & + & + & - & + & - & - & + & - & - & - & Kristal-vitrik tüf \\
\hline DUP-4 & + & \pm & - & - & - & - & - & + & - & - & Kristal-vitrik tüf \\
\hline DUP-5 & + & \pm & - & - & + & - & - & + & - & - & Vitrik tüf \\
\hline DUP-6 & + & + & - & + & + & - & + & + & - & - & Vitrik tüf \\
\hline DUP-7 & + & + & - & + & - & - & + & - & - & - & Vitrik-kristal tüf \\
\hline DUP-8 & + & + & + & + & - & - & + & \pm & - & - & Kristal-vitrik tüf \\
\hline DUP-10 & + & + & - & - & - & - & \pm & + & + & - & Vitrik tüf \\
\hline DUP-13 & + & + & - & - & - & - & \pm & + & + & - & Silisli tüf \\
\hline DUP-15 & + & + & - & + & - & + & + & - & - & - & Kristal-vitrik tüf \\
\hline DUP-16 & + & + & \pm & + & - & - & - & - & + & - & Vitrik-kristal tüf \\
\hline DUP-17 & + & - & + & + & - & - & - & \pm & - & - & Kristal tüf \\
\hline DUP-20 & + & + & - & + & - & \pm & + & + & - & + & Litik-vitrik tüf \\
\hline DUP-21 & + & + & - & + & + & - & + & - & + & - & Kristal-vitrik tüf \\
\hline DUP-25 & + & \pm & + & + & - & - & - & - & + & - & Kristal-vitrik tüf \\
\hline DUP-27 & + & - & + & + & - & - & - & + & - & - & Vitrik-kristal tüf \\
\hline DUP-43 & + & + & - & - & - & - & + & + & + & - & Kristal tüf \\
\hline DUP-48 & + & + & - & + & - & - & - & \pm & - & - & Vitrik-kristal tüf \\
\hline DUP48-1 & + & + & + & + & - & - & - & \pm & - & - & Kristal tüf \\
\hline DUP-54 & + & + & + & + & - & - & - & + & + & - & Kristal-vitrik tüf \\
\hline DUP-56 & + & + & - & + & - & + & + & + & + & - & Kristal-vitrik tüf \\
\hline DUP58-1 & + & \pm & \pm & \pm & + & - & - & + & - & - & Vitrik tüf \\
\hline DUP-59 & + & + & - & - & - & - & - & - & - & + & Litik-kristal-vitrik tüf \\
\hline DUP62-1 & + & + & + & + & - & - & - & - & + & - & Kristal tüf \\
\hline DUP-71 & + & + & + & + & - & - & - & + & + & - & Kristal-vitrik tüf \\
\hline DUP-75 & + & - & + & \pm & - & - & - & \pm & - & + & Litik-kristal-vitrik tüf \\
\hline DUP-76 & + & + & + & - & - & - & - & - & - & - & Vitrik tüf \\
\hline DUP-78 & + & \pm & + & + & - & - & - & + & - & - & Vitrik-kristal tüf \\
\hline DUP-81 & + & \pm & \pm & + & + & - & - & + & + & - & Vitrik-kristal tüf \\
\hline DUP-82 & + & + & + & + & - & - & + & - & + & - & Kristal-vitrik tüf \\
\hline DUP-83 & + & - & + & + & - & - & - & + & + & - & Vitrik-kristal tüf \\
\hline DUP85-1 & + & \pm & + & + & - & - & - & + & - & - & Vitrik-kristal tüf \\
\hline DUP85-2 & + & + & - & + & - & - & - & + & - & - & Kristal-vitrik tüf \\
\hline DUP-86 & + & + & + & + & - & - & - & + & - & - & Kristal-vitrik tüf \\
\hline DUP-88 & + & + & \pm & - & - & - & - & - & - & - & Kristal-vitrik tüf \\
\hline DUP-89 & + & + & + & \pm & - & - & + & - & - & + & Litik-kristal-vitrik tüf \\
\hline DUP-90 & + & \pm & \pm & + & \pm & - & \pm & - & - & + & Litik-kristal-vitrik tüf \\
\hline DUP-108 & + & + & - & - & - & - & + & - & - & + & Litik-vitrik tüf \\
\hline DUP-110 & \pm & + & - & + & - & - & + & + & + & - & Kristal-vitrik tüf \\
\hline
\end{tabular}

(Q; kuvars, San; sanidin, Pl; plajiyoklas, Bi; Biyotit, Kal; kalsedon, Klst; kalsit, Ser; serizit, Op; opak mineral, Fe; demiroksit minerali)

\subsection{Petrografi}

Çalışma alanındaki Civanadağ tüfleri üzerinde yapılan petrografik çalışmalara göre; birimin alt fasiyes (beyazımsı, grimsi renkli pomzaca zengin) ve üst fasiyes (ince taneli laminalı) olmak üzere iki fasiyesten oluştuğu belirlenmiştir. Alt fasiyes metamorfik çakıl içerikli pomzaca zengin litik tüfler ile başlamakta, devamlı olmayan pomza yığışımları içeren litik-vitrik tüflü seviyeler ile devam etmektedir. Üst fasiyes ise pembe renkli litik vitrik tüf ve vitrik tüfler ile 
başlamakta ve beyazımsı gri renkli litik vitrik tüfler ile devam etmektedir. En üst seviyesi ise, yeşil renkli bol mikalı kristal vitrik tüfler ile temsil edilmektedir. Laminalı fasiyesten alınan örneklerin mikroskobik incelemelerinde litik-vitrik tüf, kristal-vitrik tüf, vitrik-tüf olarak adlandırılmıştır. Tüflerde mineral içeriğinin; sanidin, plajiyoklas, kuvars ve üst seviyelerdeki tüflerde de bol biyotit içeriği olduğu tesbit edilmiştir.

Civanadăg tüflerinin mikroskobik incelemelerinde saptanan pirojen mineraller; kuvars + sanidin + plajioklas + biyotit \pm amfibol, sekonder mineraller; + kalsedon + kalsit + serizit + demiroksit + opak mineral + sekonder kuvars’tır (Tablo 1).

Bölgedeki tüflerde genellikle vitrofirik doku, mikrokristal doku, sferulitik doku ve felsitik dokulara rastlanılmıştır. Sferulitik dokular volkan camının devitrifikasyonu sonucu oluşmuştur. Ayrıca tüflerde akma bandı yapısı görülmüştür. Hamur içinde cam kıymıkları (glass shard) ve pümis (pomza) parçalarına da rastlanılmıştır.

Tüflerdeki kuvarslar bol farklı boyutlu ve iri taneli olarak tespit edilmiş olup kuvarslardaki kemirilme ve kırılmalarda dikkat çekmektedir (Şekil 7a,b,c,d). Potasyumlu feldispatlardan sanidin hâkimdir. Genelde sanidinler iri taneli, öz ve yarı öz şekilli ve bozuşmuş olarak bulunmaktadır. Sanidinlerde serizitleşme ve killeşme tespit edilmiştir.
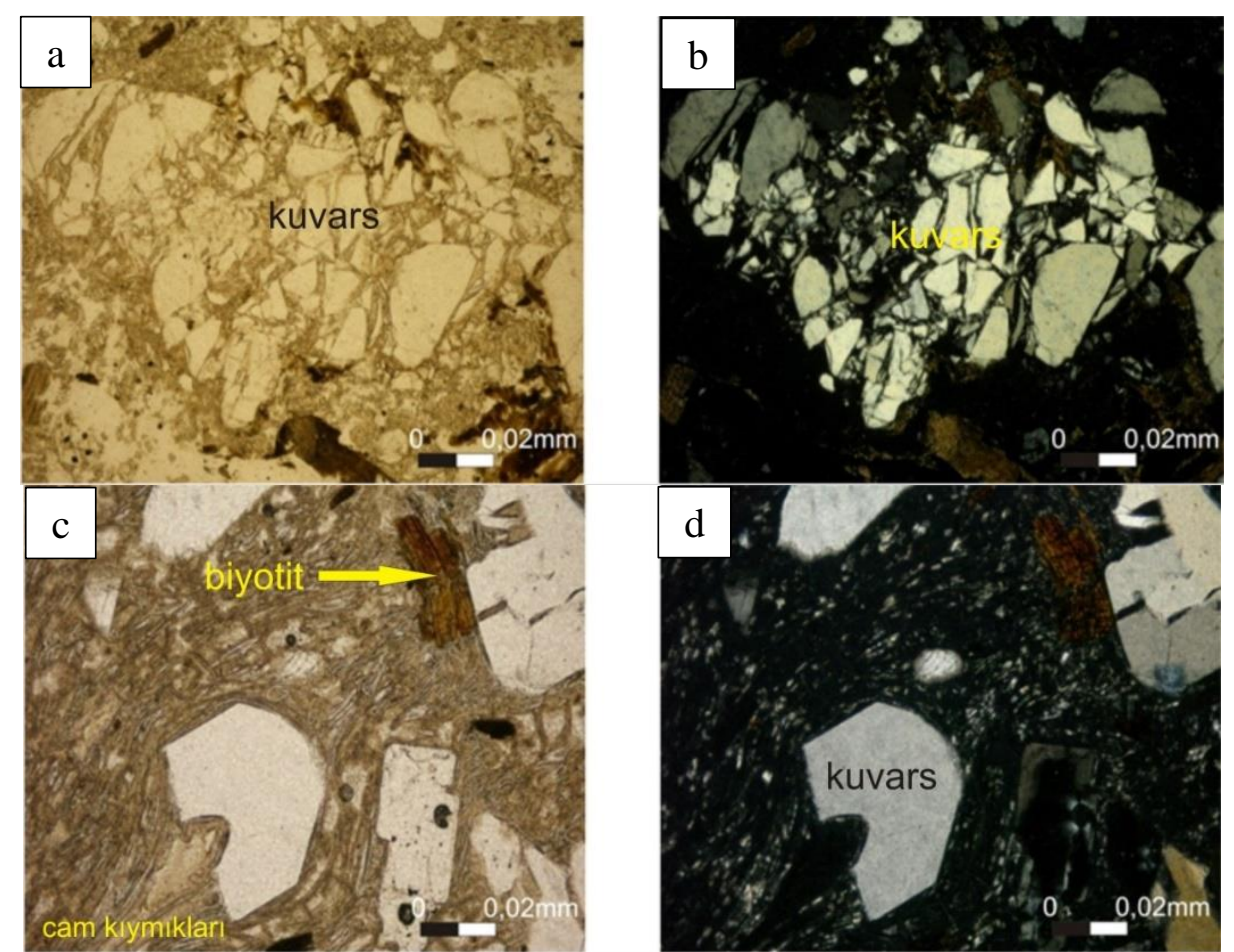

Şekil 7. a-b) DUP-16 nolu Tüf örneğinde kırılmış kuvars kristallerinin (sol taraf tek ve sağ taraf çift nikol) mikroskopta görünümü. c-d) DUP-78 nolu tüf örneğinin cam kıymıklarının dizilimi ve kemirilmiş kuvars kristalinin (sol taraf tek ve sağ taraf çift nikol) görünüm.

Biyotitler öz şekilli ve yarı öz şekilli olarak bulunmaktadır (Şekil 8a, b). Biyotitler koyu kahverenkli, tek yönde dilinimleri ile tanınmaktadır (Şekil 8c, d). Bunun yanı sıra biyotitlerde 
eğilme bükülme ve kırılmalar vardır (Şekil 9a, b). Biyotitlerde kloritleşme, demiroksitli alterasyon ve opasitleşme bulunmaktadır (Şekil 9c, d). Plajioklaslar polisentetik ve zonlu sönme göstermekte olup sönme açılarından oligoklas ve andezin karakterde oldukları hesaplanmıştır (Şekil 9c, d). Plajiyoklas mineralleri çoğunlukla serizitleşme ve killeşme türü bozunmalar göstermektedir. Amfibol mineralleri öz ve yarı öz şekilli olarak tespit edilmiştir. Amfiboller diğer minerallere göre daha azdır. Amfibollerde de kloritleşme türü alterasyon tespit edilmiştir (Şekil 9e, f).

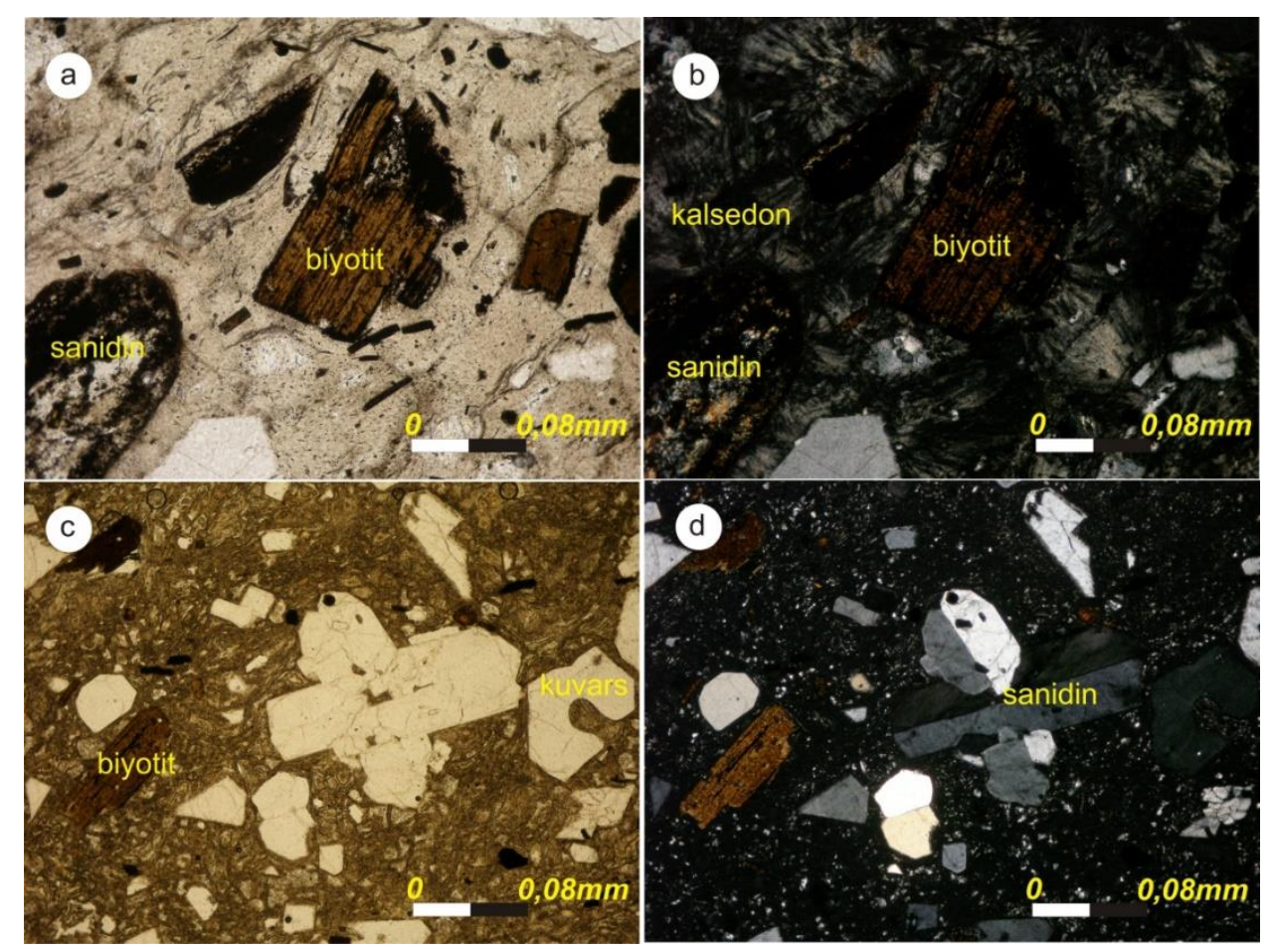

Şekil 8. a-b) DUP-21 nolu kristal vitrik tüf örneğindeki öz ve yarı öz şekilli biyotit kristali, kalsedon kristalinden görünüm.Vitrofirik dokuya sahiptir (sol taraf tek, sağ taraf çift nikol). c-d) DUP-85-2 nolu kristal vitrik tüf örneğindeki tek yönde dilimili biyotit minerali, öz ve yarı öz şekilli sanidin minerali ve kuvars mineralinden görünüm. Mikrokristalli doku görülmekte (sol taraf tek, sağ taraf çift nikol).

$\mathrm{Bu}$ bölgedeki tüfler hidrotermal alterasyona uğradıklarından feldispatlarda serizitleşme, sossuritleşme, killeşme görülmektedir. Ayrıca limonitleşme ve hematitleşmeler vardır. Civanadağ tüfleri tektonizma veya bir sonraki volkanizmanın etkisi ile silisleşmiştir. Bu tüflerdeki sekonder kuvars oluşumu yüksek 1sılı ortam sonucu oluştuğunu göstermekte ve tüflerde akıntı yapıları izlenmektedir. Ayrıca mikroskobik incelemelerde görülen kalsedon oluşumları ise silisleşmenin nispeten daha düşük ortamda gerçekleştiğini gösterir. Piroklastlarda sanidinin sekonder kuvarsa dönüşümüde görülmüş olup, tüflerde silisleşme genelde $\% 40$ - 50 civarındadır. 


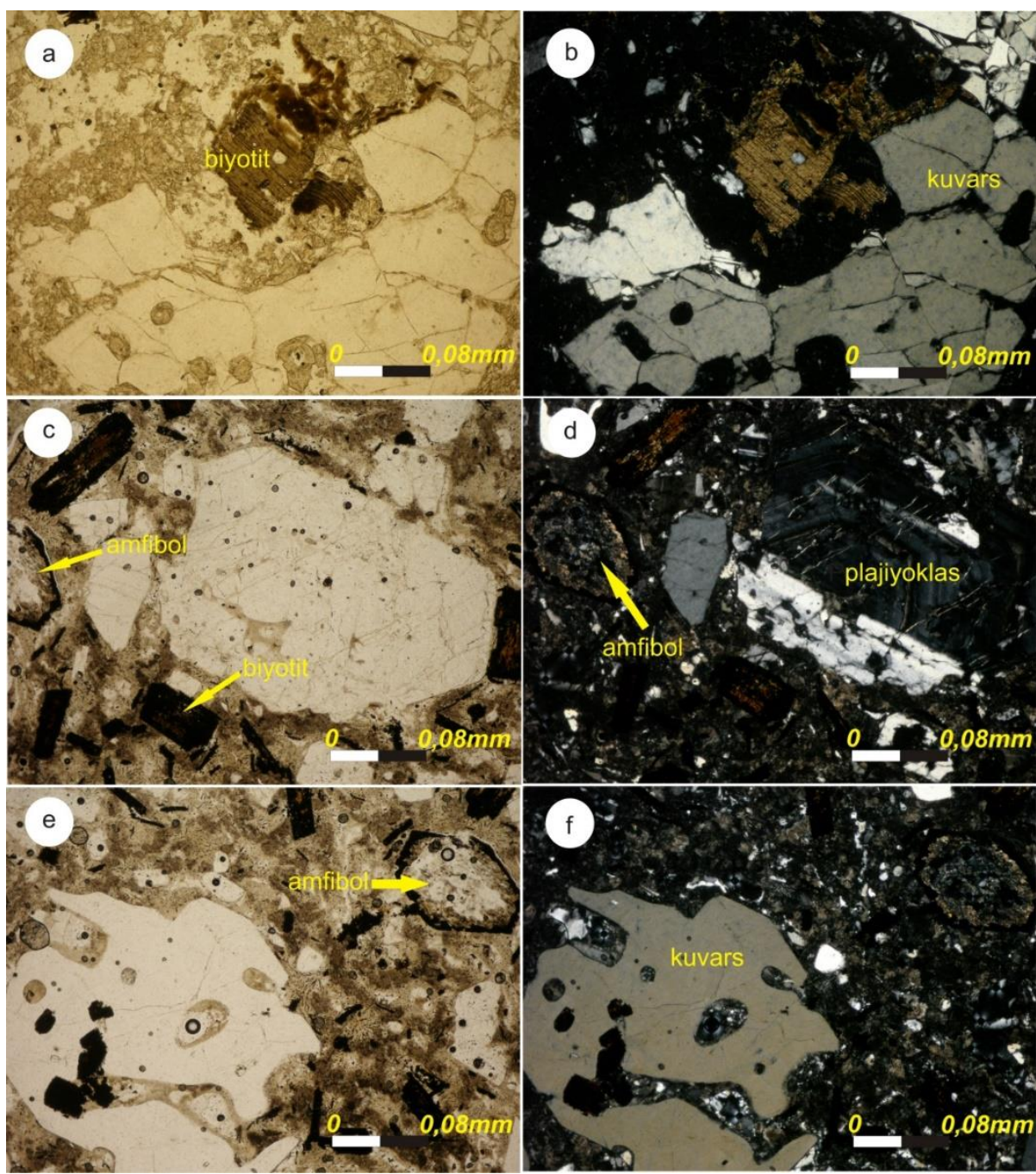

Şekil 9. a-b) DUP-16 nolu vitrik kristal tüf örneğindeki kırılmış, eğilmiş, bükülmüş biyotit kristali ve elek dokulu kuvars kristalinden görünüm. c-d) DUP-17 nolu kristal tüf örneğindeki kloritleşmiş ve opasitleşmiş amfibol minerali, zonlu plajiyoklas ve opasitleşmiş ve demiroksitlenmiş biyotit mineralinden görünüm. e-f) DUP-17 nolu kristal tüf örneğindeki kemirilmiş kuvars ve kloritleşmiş amfibol mineralinden görünüm(sol taraf tek sağ taraf çift nikol)

\subsection{Jeokimya}

İnceleme alanında alınan örneklerin petrografik tanımlamaları yapıldıktan sonra içinden taze ve altere olmamış numuneler seçilmiştir. İncelenen örneklerin tüm kayaç ana oksit, iz ve nadir toprak element içerikleri Tablo 2'de verilmiştir.

\subsection{Ana Element Oksit Jeokimyası}

Civanadağ Tüfleri, Le Maitre [34], kayaç adlamasına dayalı toplam alkaliye dayalı karşı silis (TAS) diyagramına göre riyolit ve dasit alanlarında yer almıştır (Şekil 10). Aynı diyagram üzerindeki [35] alkali-subalkali ayrım diyagramında örnekler subalkali alana düşmektedir. Subalkali karakterdeki örnekler AFM $\left(\mathrm{Na}_{2} \mathrm{O}+\mathrm{K}_{2} \mathrm{O}, \mathrm{FeO}(\mathrm{t}), \mathrm{MgO}\right)$ diyagramında [35] kalkalkalin karaktere sahip oldukları görülmektedir (Şekil 11). 
Tablo 2. Örneklerin tüm kayaç ana oksit, iz ve nadir toprak element içerikleri (\%)

\begin{tabular}{|c|c|c|c|c|c|c|c|}
\hline Major elementler & DUP-3 & DUP-7 & DUP-16 & DUP-20 & DUP-21 & DUP-27 & DUP-90 \\
\hline $\mathrm{SiO}_{2}$ & 73.41 & 71.69 & 65.15 & 68.42 & 67.12 & 70.53 & 71.31 \\
\hline $\mathbf{A l}_{2} \mathbf{O}_{3}$ & 13.63 & 14.42 & 14.67 & 11.66 & 15.46 & 13.65 & 11.39 \\
\hline $\mathrm{Fe}_{2} \mathrm{O}_{3}$ & 0.43 & 2.68 & 2.56 & 2.28 & 3.32 & 2.59 & 0.92 \\
\hline MgO & 0.23 & 0.38 & 1.26 & 1.14 & 0.87 & 0.99 & 0.42 \\
\hline $\mathrm{CaO}$ & 0.04 & 0.24 & 3.22 & 4.47 & 1.30 & 1.76 & 1.77 \\
\hline $\mathrm{Na}_{2} \mathrm{O}$ & 0.06 & 0.13 & 1.70 & 0.08 & 2.99 & 4.06 & 0.84 \\
\hline $\mathrm{K}_{2} \mathrm{O}$ & 9.95 & 7.46 & 2.94 & 5.39 & 5.96 & 3.67 & 4.61 \\
\hline $\mathrm{TiO}_{2}$ & 0.43 & 0.34 & 0.39 & 0.34 & 0.46 & 0.39 & 0.07 \\
\hline $\mathrm{P}_{2} \mathrm{O}_{5}$ & 0.04 & 0.14 & 0.09 & 0.11 & 0.16 & 0.14 & $<0.01$ \\
\hline $\mathrm{MnO}$ & $<0.01$ & 0.02 & 0.03 & 0.07 & 0.4 & 0.06 & 0.01 \\
\hline $\mathrm{Cr}_{2} \mathrm{O}_{3}$ & $<0.002$ & $<0.002$ & 0.002 & 0.002 & 0.002 & $<0.002$ & $<0.002$ \\
\hline Ateş Zaiyatı & 1.6 & 2.3 & 7.7 & 5.8 & 2.1 & 2.0 & 8.6 \\
\hline Toplam & 99.85 & 99.84 & 99.69 & 99.77 & 99.79 & 99.80 & 99.92 \\
\hline \multicolumn{8}{|c|}{ İz elementler (ppm) } \\
\hline $\mathbf{B a}$ & 973 & 926 & 1231 & 1416 & 1218 & 967 & 142 \\
\hline $\mathbf{R b}$ & 360.2 & 353.9 & 112.3 & 257.9 & 210.3 & 154.6 & 142.2 \\
\hline $\mathrm{Sr}$ & 33.5 & 49.3 & 933.1 & 152.0 & 206.5 & 396.1 & 51.1 \\
\hline $\mathbf{Y}$ & 15.1 & 21.9 & 21.3 & 17.6 & 22.6 & 18.4 & 24.1 \\
\hline $\mathbf{Z r}$ & 155.9 & 174.5 & 187.0 & 115.1 & 169.2 & 165.3 & 83.1 \\
\hline $\mathrm{Nb}$ & 13.2 & 15.1 & 15.2 & 9.8 & 12.9 & 12.6 & 15.5 \\
\hline Th & 17.1 & 22.7 & 26.2 & 14.5 & 18.9 & 18.2 & 27.5 \\
\hline $\mathbf{P b}$ & 15.0 & 11.1 & 23.4 & 17.4 & 21.1 & 21.7 & 33.7 \\
\hline $\mathbf{G a}$ & 12.3 & 15.7 & 15.5 & 11.9 & 14.1 & 13.2 & 12.7 \\
\hline $\mathrm{Zn}$ & 1 & 20 & 25 & 28 & 17 & 38 & 19 \\
\hline $\mathrm{Cu}$ & 3.8 & 2.4 & 3.2 & 4.9 & 0.5 & 3.2 & 1.5 \\
\hline $\mathbf{N i}$ & 17.5 & 12.8 & 10.8 & 16.2 & 10.0 & 11.9 & 16.9 \\
\hline $\mathbf{V}$ & 38 & 25 & 45 & 29 & 36 & 31 & $<8$ \\
\hline Hf & 4.6 & 5.0 & 5.8 & 3.6 & 4.9 & 4.6 & 2.8 \\
\hline Cs & 6.3 & 30.6 & 16.9 & 42.7 & 15.2 & 19.1 & 8.1 \\
\hline Sc & 5 & 5 & 7 & 6 & 8 & 6 & 2 \\
\hline Ta & 2.2 & 2.3 & 2.0 & 1.6 & 1.6 & 1.6 & 2.0 \\
\hline Co & 29.4 & 27.4 & 23.9 & 26.5 & 19.1 & 22.6 & 32.5 \\
\hline $\mathbf{B e}$ & 1 & 3 & 3 & 2 & 3 & 2 & 3 \\
\hline $\mathbf{U}$ & 4.7 & 5.2 & 5.6 & 2.9 & 4.8 & 5.7 & 6.3 \\
\hline $\mathbf{W}$ & 250.5 & 191.8 & 143.7 & 176.5 & 118.8 & 137.0 & 213.2 \\
\hline Sn & 3 & 5 & 4 & 3 & 4 & 4 & 3 \\
\hline Mo & 1.2 & 0.1 & 0.2 & 0.2 & 0.2 & 0.1 & 0.3 \\
\hline Au & 12.7 & $<0.5$ & $<0.5$ & 0,6 & $<0.5$ & $<0.5$ & $<0.5$ \\
\hline As & 159.6 & 2.6 & 2.0 & 2.4 & 37.3 & 3.6 & 2.2 \\
\hline Cd & $<0.1$ & $<0.1$ & $<0.1$ & $<0.1$ & $<0.1$ & $<0.1$ & $<0.1$ \\
\hline Sb & 2.3 & 1.4 & $<0.1$ & $<0.1$ & 1.4 & $<0.1$ & $<0.1$ \\
\hline $\mathbf{B i}$ & $<0.1$ & $<0.1$ & 0.4 & 0.4 & $<0.1$ & 0,1 & 0.2 \\
\hline Ag & 1.1 & $<0.1$ & $<0.1$ & $<0.1$ & $<0.1$ & $<0.1$ & $<0.1$ \\
\hline Hg & $<0.01$ & $<0.01$ & $<0.01$ & 0.01 & $<0.01$ & $<0.01$ & $<0.01$ \\
\hline TI & 0.2 & 0.1 & 0.3 & $<0.1$ & $<0.1$ & $<0.1$ & 0.9 \\
\hline Se & $<0.5$ & $<0.5$ & $<0.5$ & $<0.5$ & $<0.5$ & $<0.5$ & $<0.5$ \\
\hline \multicolumn{8}{|c|}{ NTE (Nadir Toprak Element) ppm } \\
\hline La & 32.8 & 37.3 & 41.5 & 23.3 & 32.2 & 27.6 & 29.3 \\
\hline $\mathrm{Ce}$ & 62.0 & 72.8 & 73.7 & 45.2 & 63.5 & 55.5 & 59.0 \\
\hline Pr & 6.21 & 7.84 & 8.03 & 4.92 & 6.77 & 5.87 & 6.63 \\
\hline Nd & 21.5 & 27.9 & 27.5 & 18.0 & 24.9 & 21.0 & 21.6 \\
\hline Sm & 3.49 & 5.14 & 4.77 & 3.32 & 4.46 & 3.99 & 4.81 \\
\hline Eu & 0.73 & 0.81 & 0.97 & 0.70 & 0.90 & 0.80 & 0.33 \\
\hline Gd & 2.67 & 4.28 & 3.96 & 2.96 & 4.01 & 3.52 & 3.99 \\
\hline $\mathbf{T b}$ & 0.44 & 0.71 & 0.64 & 0.51 & 0.69 & 0.58 & 0.70 \\
\hline Dy & 2.32 & 3.88 & 3.59 & 2.81 & 3.76 & 3.19 & 3.79 \\
\hline Ho & 0.44 & 0.76 & 0.71 & 0.57 & 0.76 & 0.62 & 0.81 \\
\hline Er & 1.45 & 2.22 & 2.07 & 1.75 & 2.23 & 1.88 & 2.55 \\
\hline $\mathbf{T m}$ & 0.23 & 0.34 & 0.32 & 0.27 & 0.34 & 0.29 & 0.40 \\
\hline Yb & 1.56 & 2.28 & 2.21 & 1.78 & 2.26 & 1.94 & 2.38 \\
\hline Lu & 0.25 & 0.34 & 0.34 & 0.27 & 0.35 & 0.30 & 0.39 \\
\hline
\end{tabular}




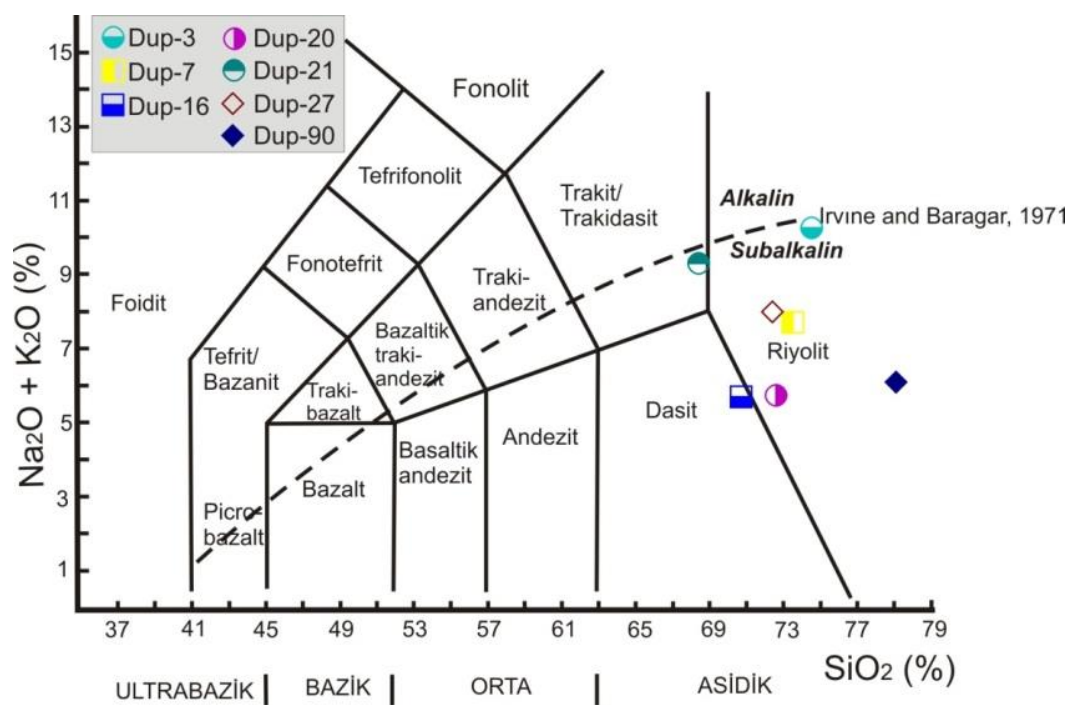

Şekil 10. Örneklerin $\mathrm{SiO}_{2}$ 'ye karşı $\mathrm{Na}_{2} \mathrm{O}+\mathrm{K}_{2} \mathrm{O}$ diyagramındaki dağılımları [34] ve alkali-yarıalkali eğrisi [35].

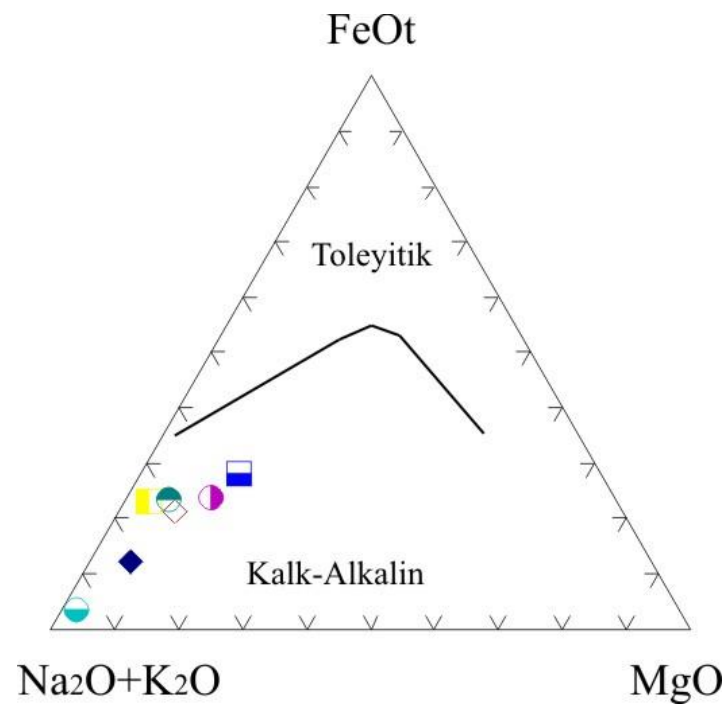

Şekil 11. Örneklerin $\mathrm{AFM}\left(\mathrm{Na}_{2} \mathrm{O}+\mathrm{K}_{2} \mathrm{O}, \mathrm{FeO}(\mathrm{t}), \mathrm{MgO}\right)$ diyagramı [35].

Çalışma alanına ait tüflerden alınan 7 adet örneğin, ana oksit elementlerinin $\mathrm{SiO}_{2}$ 'ye karşı davranışlarını incelemek amacı ile element değişim diyagramları çizilmiştir (Şekil 12). Tüf örneklerinin $\mathrm{SiO}_{2}$ içeriği \% 68.70-78.08 arasında değişmektedir. Örneklerin $\mathrm{Al}_{2} \mathrm{O}_{3}$ içeriği \%12.40-15.94, $\mathrm{Fe}_{2} \mathrm{O}_{3}$ içeriği \%0.43-3.39, $\mathrm{MgO}$ içeriği \%0.23-1.36, $\mathrm{CaO}$ içeriği \%0.04-4.75, $\mathrm{Na}_{2} \mathrm{O}$ içeriği \%0.06-4.15, $\mathrm{K}_{2} \mathrm{O}$ içeriği \%3.19-10.12, $\mathrm{TiO}_{2}$ içeriği \%0.07-0.47, $\mathrm{P}_{2} \mathrm{O}_{5}$ içeriğ \%0.01-0.16, MnO içeriği \% 0.01-0.07, $\mathrm{Cr}_{2} \mathrm{O}_{3}$ içeriği \%0.0019-0.002 arasında değişmektedir. Ana oksit element değişim diyagramlarında, $\mathrm{Al}_{2} \mathrm{O}_{3}, \mathrm{TiO}_{2}, \mathrm{P}_{2} \mathrm{O}_{5}, \mathrm{CaO}, \mathrm{Fe}_{2} \mathrm{O}_{3}, \mathrm{MgO}$ ve $\mathrm{MnO}$ $\operatorname{artan} \mathrm{SiO}_{2}$ değeri ile düzenli şekilde azalarak negatif korelasyon göstermektedir (Şekil 12a, b, c, e, f, g, 1). $\mathrm{Na}_{2} \mathrm{O}$ değerlerinde ise nispeten yatay bir trend göze çarpmış olmasına rağmen negatif eğilimlidir (Şekil $12 \mathrm{~h}$ ). $\mathrm{K}_{2} \mathrm{O}$ değeride nispeten düzensiz olmasına rağmen pozitif korelasyon göstermektedir (Şekil 12d). 
Genel olarak incelenen tüflerin silis içeriği arttıkça, uyumsuz element içeriklerinin artması ve uyumlu element içeriklerinin azalması fraksiyonel kristalleşme ile açıklanmaktadır. $\mathrm{Bu}$ özellikte kayaçların bir ana magmadan fraksiyonel kristalleşme ile türemiş olabileceklerini, ancak bunun kayaçların gelişiminde ana magmatik olay olmadığını ve diğer magmatik olaylarında (magma karışımı, kabuk kontaminasyonu v.b) rol aldığına işaret etmektedir. $\mathrm{K}_{2} \mathrm{O}$ ' nun $\mathrm{SiO}_{2}$ ile olan pozitif ilişkisi uyumsuz bir element olduğunu göstermektedir. İncelenen tüflerde bu pozitif korelasyon, bu elementlerin muhtemelen kabuk kirlenmesi ve alterasyon nedeniyle zenginleştiklerini göstermektedir. $\mathrm{SiO}_{2}$ artışı ile $\mathrm{MgO}, \mathrm{CaO}$ ve $\mathrm{Al}_{2} \mathrm{O}_{3}$ azalması önemli ölçüde klinopiroksen ve plajiyoklas fraksiyonlaşmasını yansıtmakla birlikte bu elementlerin uyumlu olduklarını göstermektedir. $\mathrm{SiO}_{2}$ artışına karşın $\mathrm{Al}_{2} \mathrm{O}_{3}$ azalması, tüflerin gelişiminde plajiyoklas ve hornblend fraksiyonlaşmasınında etkili olabileceğini göstermektedir. $\mathrm{SiO}_{2}$ artışıyla $\mathrm{Fe}_{2} \mathrm{O}_{3}$ ve $\mathrm{TiO}_{2}$ azalması rutil, ilmenit, manyetit, titanomanyetit (Fe-Ti oksitler) fraksiyonlaşmasını ifade etmektedir. $\mathrm{SiO}_{2}$ 'ye karş1 $\mathrm{P}_{2} \mathrm{O}_{5}$ değişim diyagramında gözlenen negatif korelasyon apatit fraksiyonlaşmasını yansıtmaktadır. Ana element değişimlerindeki düzgün yönsemeler fraksiyonlaşmadan, düzensiz yönsemeler ise kısmen alterasyondan kaynaklanabilir.
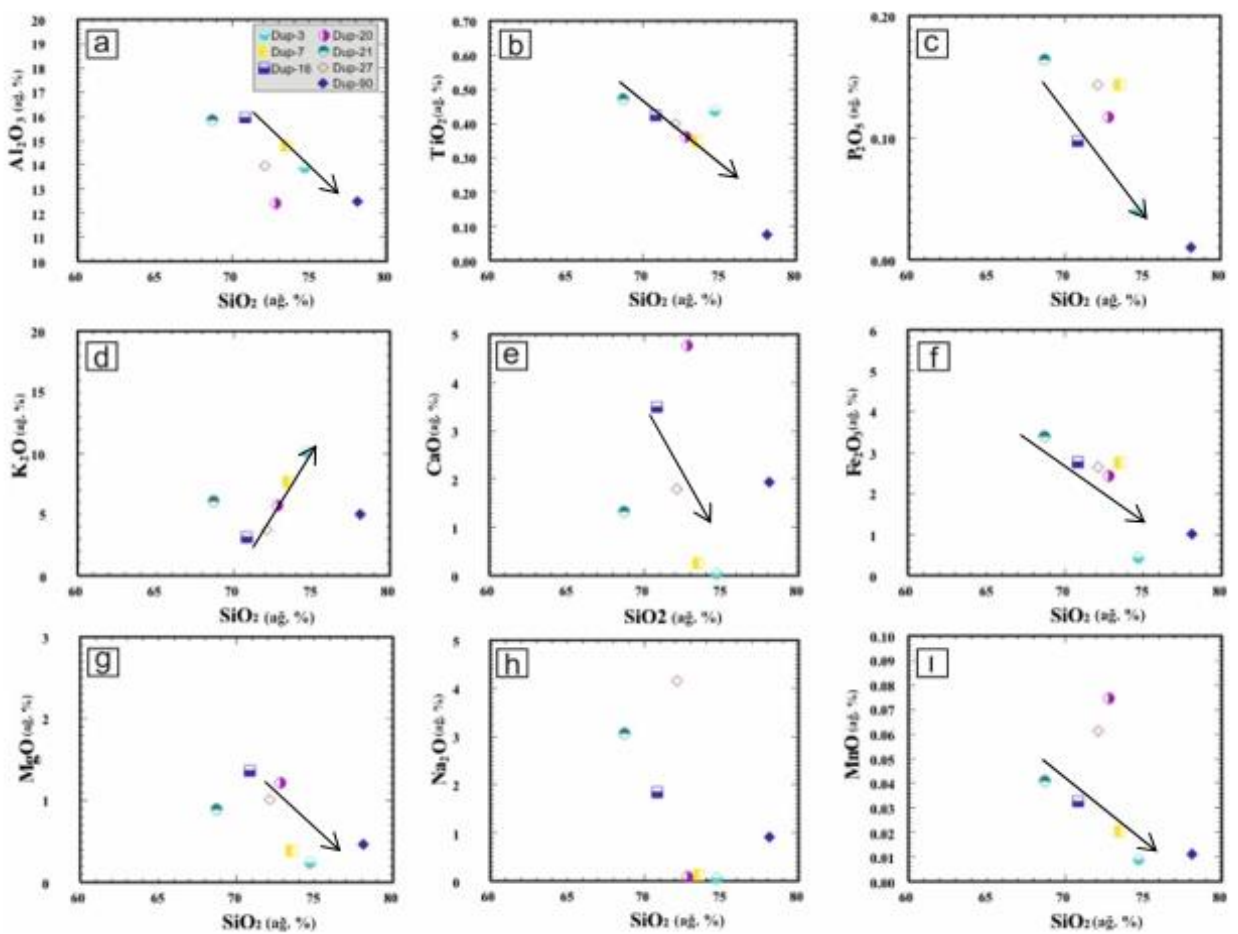

Şekil 12. Piroklastik kayaçların $\mathrm{SiO}_{2}$ 'ye karşı ana element değişim diyagramları

\section{6. İz Element Jeokimyası}

İz element değişim diyagramlarında, $\mathrm{Rb}, \mathrm{Nb}$, Ta ve Th değeride nispeten düzensiz olmasına rağmen pozitif korelasyon göstermektedir (Şekil 13a, e, f, h). Ba, Hf, $\mathrm{Sr}$ ve $\mathrm{Zr}$ artan $\mathrm{SiO}_{2}$ değeri 
ile düzenli şekilde azalarak negatif korelasyon göstermektedir (Şekil 13b, c, d, g). Rb elementi iyon yarıçapının büyük olması sebebiyle, fraksiyonel kristallenme sürecinde özellikle K'lu minerallerin (K-feldispat, biyotit) bünyesine girerler ve bu minerallerin oluşumuna kadar eriyik içerisinde zenginleşirler. Magmatik eriyik içinde $\mathrm{K}$ içeren minerallerin (K-feldispat ve biyotit) en son kristallenen ürün olmaları nedeniyle $\mathrm{Rb}$ elementinde $\mathrm{SiO}_{2}$ ' nin artışına paralel olarak artış görülür. $\mathrm{SiO}_{2}$ 'ye karşı $\mathrm{Ba}$ içeriğinin önce artıp, daha sonra azalma göstermesi riyolit türü tüflerde sanidin oluşumunu göstermektedir [36]. Hf ve Zr elementleri benzer iyon yarıçaplarına sahip oldukları için magmatik sistemde beraber hareket ederler. Zr kristallenme süresince en son kristallenen ürünler içerisinde fazla miktarlarda görülür [37]. $\mathrm{SiO}_{2}$ artışı ile $\mathrm{Sr}$ azalması önemli ölçüde plajiyoklas fraksiyonlaşmasını yansıtmakla birlikte bu elementin uyumlu olduğunu göstermektedir. Th'nin $\operatorname{artan} \mathrm{SiO}_{2}$ içeriğine karş1lık artış göstermesi Th'nin fraksiyonel kristallenme sürecinde eriyik fazı tercih etmesi ile ilişkilidir.

Örneklerin ilksel mantoya ve kondrite göre normalize edilmiş [38] iz element dağılımları çizilerek ana mağması belirlenmeye çalışılmıştır (Şekil 14a, b) İlksel Mantoya normalize edilmiş örümcek diyagramlarına bakıldığında, göze çarpan ana özellikler; belirgin bir büyük iyon yarıçaplı litofil element (LILE), ( $\mathrm{Cs}, \mathrm{K}_{2} \mathrm{O}, \mathrm{Rb}, \mathrm{Ba}$, Th, U, vd.) zenginleşmesi ve kalıcılığ yüksek elementlerde (HFSE) $\left(\mathrm{Nb}, \mathrm{P}_{2} \mathrm{O}_{5}, \mathrm{Ti}_{2} \mathrm{O}\right)$ belirgin negatif anomali ile REE (Rare Earth Elements=Nadir Toprak Elementleri)'lerde tüketilmelerdir. İlksel mantoya göre özellikle Dup3 ve Dup-90 nolu numunelerde $\mathrm{Sr}, \mathrm{P}_{2} \mathrm{O}_{5}$ ve $\mathrm{TiO}_{2}$ değerlerinde belirgin bir negatif anomali göstermiştir (Şekil 14a). Negatif $\mathrm{Nb}$ ve Ti anomalileri ana mağma gelişiminde yitim bileşeninin varlığına işaret etmektedir [39]. Ayrıca $\mathrm{Sr}$ da izlenen negatif anomali plajioklasların fraksiyonlaşmasına işaret etmektedir.

Kondrite normalize edilmiş örümcek diyagramlarına bakıldığında belirgin bir büyük iyon yarıçaplı litofil element (LILE), (Cs, K, Rb, Ba, Th, U, vd.) zenginleşmesi ve kalıcılığı yüksek elementlerden (HFSE), Pb, P, Ti da belirgin negatif anomali ile REE'lerde tüketilmeler dikkat çekmektedir (Şekil 14b). Litofil element zenginleşmesi kıtasal kabuk kirlenmesinden kaynaklanabilmektedir [36]. Ayrıca Sr da belirgin bir tüketilme göze çarpmaktadır. Bunun potayumlu feldispat yada plajiyoklas franksiyonlaşmasından kaynaklandığı düşünülmüştür. Kayaçların, büyük iyonlu litofil elementler (LILE) bakımından aşırı derecede zenginleşmesi (özellikle $\mathrm{K}, \mathrm{Rb}$ ve Th) ve Nb, Ti bakımından fakirleşmesi iz element dağılımlarında gözlenen karekteristik özelliklerdir. 


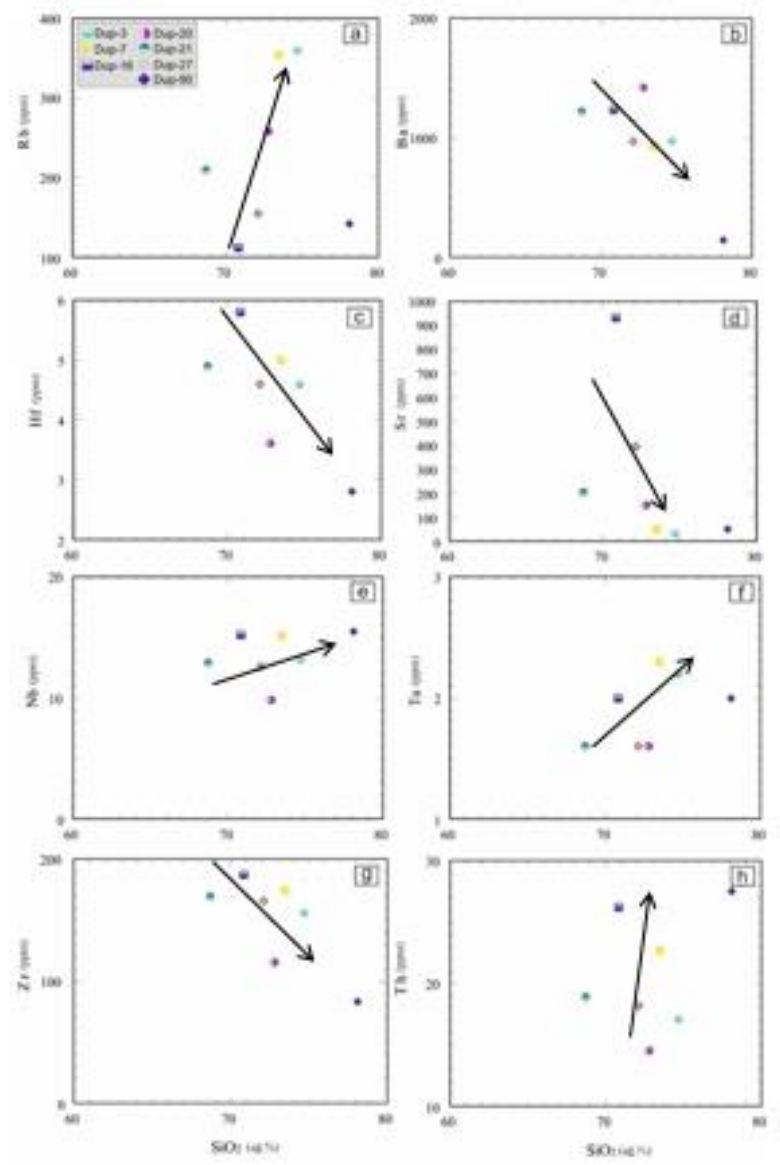

Şekil 13. Piroklastik kayaçların $\mathrm{SiO}_{2}$ ’ ye karşı iz element değişim diyagramları
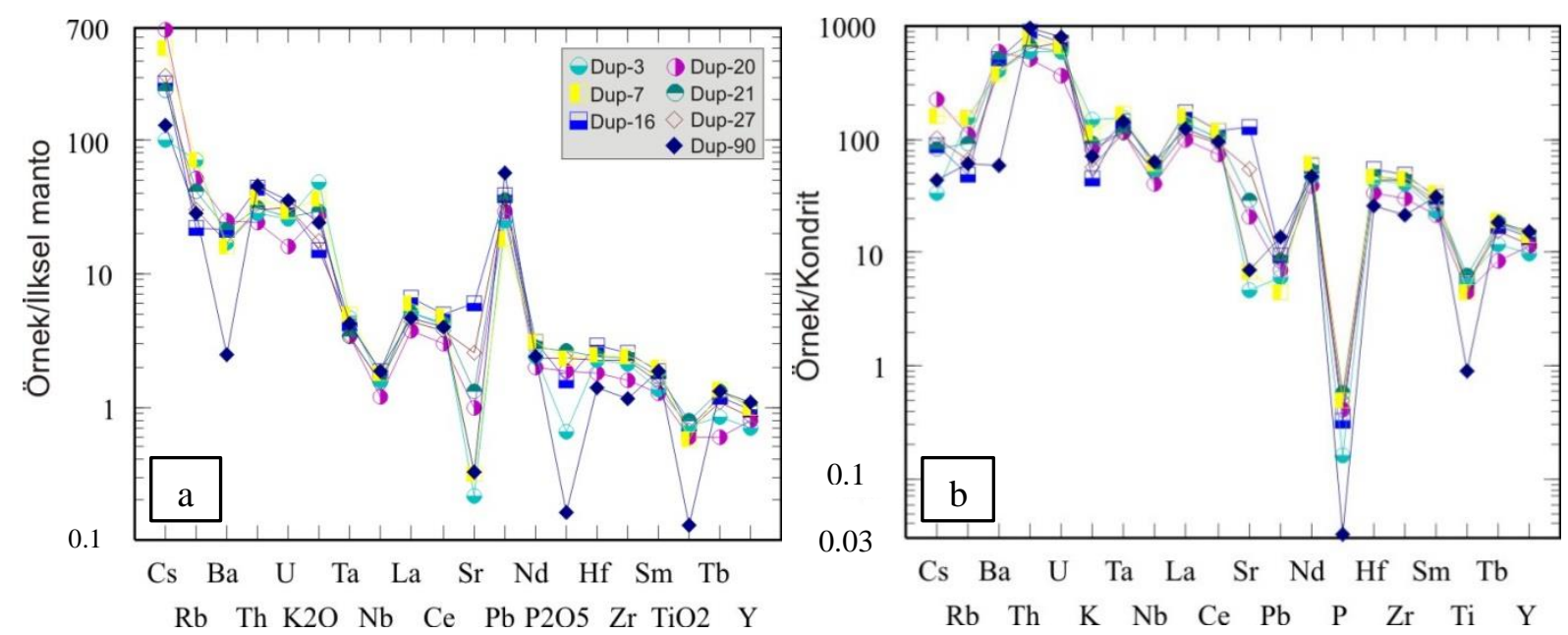

Şekil 14. a) Çalışma alanındaki tüflerin ilksel mantoya göre normalize edilmiş çoklu element dağılım örnekleri (Normalleştirme değerleri [38]' dan alınmıştır). b) Tüf örneklerinin kondrite göre normalize edilmiş çoklu element dağılım örnekleri (Normalleştirme değerleri [38]'dan alınmışıı).

\subsection{Nadir Toprak Element Jeokimyası}

İncelenen örneklerin ilksel mantoya ve kondrite göre normalize edilmiş [38] nadir toprak element dağılımlarında tüm örnekler birbirlerine çok iyi paralellik göstermektedirler (Şekil 15a, b). $\mathrm{Bu}$ da incelenen tüf örneklerinin tümünün aynı kökenden türediklerini doğrulamaktadır. Dağılımlara dikkat edildiğinde; kayaçlarda hafif nadir toprak element zenginleşmesinin 
(HNTE) orta ve ağır nadir toprak element (ANTE) zenginleşmesine göre daha fazla olduğu görülmektedir. Bunun nedeni kaynak magmaya üst kıta kabuğundan malzeme gelmesi olabilir. Kondrite ve ilksel mantoya normalize edilmiş örümcek diyagramında gözlenen bir diğer unsur, orta nadir toprak elementlerde (ONTE) belirgin bir tüketilmenin varlı̆̆ıdır. ANTE'lerde ise, ONTE'lere oranla bir miktar zenginleşme söz konusudur. Bunun sonucu olarak, yukarı doğru konveks, kaşık şekilli bir desen gözlenir. Böyle bir desenin genellikle amfibol ayrımlaşmasının sonucunda geliştiği bilinmektedir. Kayaçların tümünde negatif Eu anomalisi gözlenmektedir. Negatif Eu anomalisinin belirgin olması bu kayaçların gelişiminde plajiyoklas ayrımlaşmasının önemli bir rol oynadığını göstermektedir [40].
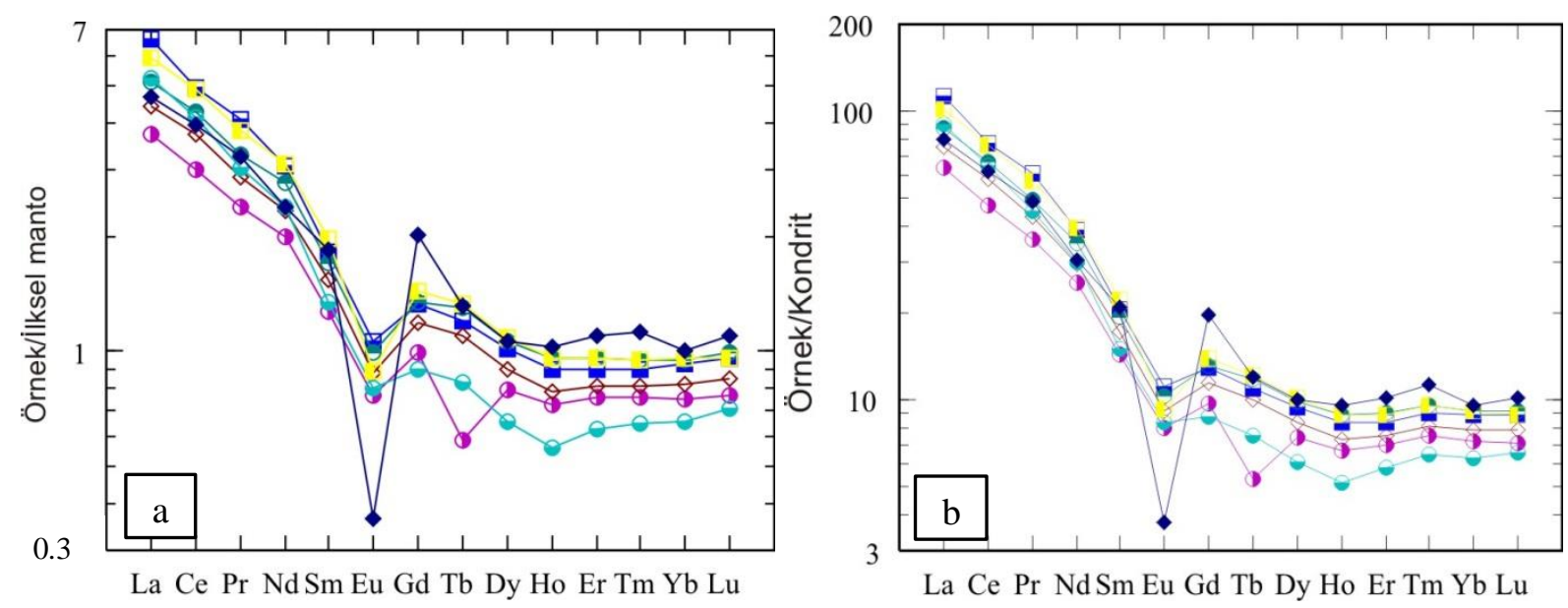

Şekil 25. a) Tüf örneklerinin ilksel mantoya göre normalize edilmiş nadir toprak elementleri dağllım çizimleri (Normalleştirme değerleri [38]'dan alınmıştır). b) Tüf örneklerinin Kondrit'e göre normalize edilmiş nadir toprak elementleri dağılım çizimleri (Normalleştirme değerleri [38]' dan alınmıştır).

\section{SONUÇLAR}

Çalışma alanı, D-B uzanımlı Kuvaterner yaşlı Simav grabenin kuzeyinde, KB-GD uzanımlı Bigadiç Borat havzasının doğusunda ve Dursunbey (Balıkesir) güneyinde yer almaktadır.

Civanadağ tüflerinin ortaya çıkarılan ölçeksiz stratigrafik istifinin alt fasiyes (beyazımsı, grimsi renkli pomzaca zengin fasiyes), üst fasiyes (ince taneli laminalı fasiyes) ve en üsttede aglomeralardan oluştuğu belirlenmiştir. Alt fasiyes, metamorfik çakıl içerikli pomzaca zengin tüfler ile başlamakta, devamlı olmayan pomza yığışımları içeren seviyeler bulundurmaktadır. Üst seviyelerde pomza boyutu ve içeriği azalmakta ve yer yer küçük boyutlu litik bileşenler içermektedir. İnce taneli ve yer yer laminalanma gösteren fasiyes altta beyaz renkli fakat yer yer pembe seviyeler içeren tüfler ile en üst zonlarında da biyotitli tüfler yer almaktadır. İnce taneli fasiyesteki renk değişimleri tüflerin mineral içerikleri ve/veya başka bir tanımla kristal yığışımlarınında mineral içeriği ile ilgili oldukları anlaşılmaktadır. Piroklastik kayaların en üst 
fasiyesini aglomeralar oluşturur. İri lav (aglomera) blokları $15 \mathrm{~cm}$ 'lik boyutlara ulaşmıştır. Taneler tüf ile bağlanmıştır.

Civanadağ tüflerinin petrografik incelemelerinde saptanan pirojen mineraller; kuvars + sanidin + plajioklas + biyotit \pm amfibol, sekonder mineraller; + kalsedon + kalsit + serizit + demiroksit + opak mineral + sekonder kuvars'tır. Genellikle vitrofirik doku, mikrokristal doku, sferolitik doku ve felsitik dokular ile ayrıca akma bandı yapısı görülmüştür. Hamur içinde cam kıymıkları (glass shard) ve pümis (pomza) parçalarıda yer almaktadır.

Tüflerin kalkalkalen karakterde, riyolit ve dasit bileşimine sahip olduğu tespit edilmiştir. Civanadağ tüflerindeki ana oksit ve iz element harker diyagramlarında, $\mathrm{Al}_{2} \mathrm{O}_{3}, \mathrm{TiO}_{2}, \mathrm{P}_{2} \mathrm{O}_{5}$, $\mathrm{CaO}, \mathrm{Fe}_{2} \mathrm{O}_{3}, \mathrm{MgO}, \mathrm{MnO}, \mathrm{Ba}, \mathrm{Hf}, \mathrm{Sr}$ ve $\mathrm{Zr}$ artan $\mathrm{SiO}_{2}$ değeri ile düzenli şekilde azalarak negatif korelasyon göstermektedir. $\mathrm{Na}_{2} \mathrm{O}$ değerlerinde ise nispeten yatay bir trend göze çarpmış olmasına rağmen negatif eğilimlidir. $\mathrm{K}_{2} \mathrm{O}, \mathrm{Rb}, \mathrm{Nb}$, Ta ve Th değeride nispeten düzensiz olmasına rağmen pozitif korelasyon göstermektedir. Gözlenen düzensiz dağılım kısmen alterasyondan kaynaklanabilir. Ancak iz elementle birlikte kontaminasyon, magma karışımıylada ilişkilendirilebilir.

İlksel Mantoya ve kondrite normalize edilmiş örümcek diyagramlarına bakıldığında belirgin bir büyük iyon yarıçaplı litofil element zenginleşmesi ve kalıcılı̆̆ 1 yüksek elementlerde belirgin negatif anomali ile REE'lerde tüketilmeler dikkat çekmektedir.

İncelenen tüflerin ilksel mantoya ve kondrite göre normalize edilmiş nadir toprak element dağılımlarının birbirleri ile çok iyi paralellik göstermesi tüf örneklerinin tümünün aynı kökenden türediklerini göstermektedir. Kayaçlarda hafif nadir toprak element zenginleşmesinin (HNTE) orta ve ağır nadir toprak element (ANTE) zenginleşmesine göre daha fazla olması kaynak magmaya üst kıta kabuğundan malzeme gelmesinden kaynaklanabilir. Kayaçların tümünde negatif Eu anomalisi gözlenmektedir.

\section{KAYNAKLAR}

[1] T. Ercan, A. Türkecan, A. Dinçel, E. Günay, Kula-Selendi (Manisa) dolaylarının jeolojisi. Jeoloji Mühendisliği, 17 (1983) 3-29.

[2] A.M.C. Şengör, Türkiye'nin Neotektoniğinin esasları. Türk. Jeol. Kur. Konf. Ser. 2 (1980) 40.

[3] A.M.C. Şengör, Cross-faults and differential stretching of hanging walls in regions of low angle normal faulting: Examples from western Turkey. In Continental Extensional Tectonics (eds M. P. Coward, J. F. Dewey and P. L. Hancock). Geological Society Special Publication no. 28 (1987) 57589.

[4] G. Seyitoğlu, B.C. Scott, Late Cenozoic crustal extension and basin formation in west Turkey. Geol. Mag., 128 (1991) 155-66.

[5] G. Seyitoğlu, B.C. Scott, The cause of N-S extensional tectonics in western Turkey: Tectonic escape vs Back-arc spreading vs orogenic collapse. J. Geodyn,. 22 (1996) 145-53. 
[6] T. Emre, Gediz grabeninin jeolojisi ve tektoniği. Türk. J. Earth Sci. 5 (1996) 171-185.

[7] G. Seyitoğlu, Late Cenozoic tectono-sedimentary development of the Selendi and Uşak-Güre basins; a contribution to the discussion on the development of east-west and North trending basins in western Anatolia. Geol. Mag. 134 (1997) 163-175.

[8] G. Seyitoğlu, A. Duncan, N. Geoff, B. Scott, The evolution from Miocene potassic to Quaternary sodic magmatism in western Turkey: implications for enrichment processes in the litospheric mantle. Jour. of theVolc. And Geoth. Res. 76 (1997) 127-147.

[9] A. Koçyiğit, H. Yusufoğlu, E. Bozkurt, Evidence from the Gediz Graben for episodic two-stage extension in western Turkey. J. Geol. Soc. London. 156 (1999) 605-616.

[10]Y. Yılmaz, Ş.C. Genç, F. Gürer, M. Bozcu, K. Yılmaz, Z. Karacık, Ş. Altunkaynak, A. Elmas, When did the western Anatolian grabens begin to develop? From: Bozkurt, E., Winchester, J.A., Piperi J.A.D. (eds.), Tectonics and Magmatism in Turkey and the Surraunding Area. J. Geol. Soc. London. 173 (2000) 131-162.

[11]E. Bozkurt, Neotectonics of Turkey - a synthesis. Geodin. Acta.14 (2001) 3-30

[12]E. Bozkurt, Origin of NE-trending basins of western Turkey. Geodin. Acta. 16 (2003) 61-81.

[13]E. Bozkurt, H. Sözbilir, Tectonic evolution of the Gediz Graben; field evidence for an episodic, twostage extension in western Turkey. Geol. Mag. 141 (2004) 63-79.

[14]M. Purvis, A.H.F. Robertson, A pulsed extension model fort he Neogene-Recent E-W-trending Alaşehir Graben and the NE-SW trending Selendi and Gördes basins, western Turkey. Tectonophysics. 391 (2004) 171-201.

[15]M. Purvis, A.H.F. Robertson, Miocene sedimentary evolution of the NE-SW-trending Selendi and Gördes basins, Western Turkey: implications for extensional processes. Sediment. Geol. 174 (2005) 31-62.

[16]M. Purvis, A.H.F. Robertson, M. Pringle, ${ }^{40} \mathrm{Ar}-{ }^{39} \mathrm{Ar}$ dating of biotite and sanidine in tuffaceous sediments and related intrusive rocks: implicationsfor the Early Miocene evolution of the Gördes and Selendi Basins, W Turkey. Geodin. Acta. 18 (2005) 239-254.

[17]Y. Ersoy, C. Helvac1, Stratigraphy and Geochemical Features of the Early Miocene Bimodal (Ultrapotassic and;Calcalkaline) volcanic activity within the NE-trending Selendi Basin, Western Anatolia, Turkey. Türk. J. Earth Sci. 16 (2007) 1-23.

[18]A.M.C. Şengör, Y. Yılmaz, Tethyan Evolution of Turkey: A Plate Tectonic Approach. Tectonophysics. 75 (1981) 181-241.

[19]E. Bingöl, M. Delaloye, G. Ataman, Granitic intrusionas in western anatolia: a contribution to the geodynamic study of this area. Eclogae Geol. Helv. 75 (1982) 437-446.

[20]F. Innocenti, P. Manetti, R. Mazzuoli, G. Pasquare, L. Villari, Regional distribution and character of active andasite volcanism-Anatolia and north-western Iran, In orogenic Andasites and Related Rocks. (ed R.S.Thorpe) pp.327-349. New Iran, In orogenic Andasites and Related Rocks (1982) 327349.

[21]E. Aldanmaz, J.A. Pearce, M.F. Thirwall, J.G. Mitchell, Petrogenetic evolution of late Cenozoic, post-collision volcanism in western Anatolia, Turkey. Jour. of Volc. and Geoth. Res. 102 (2000) 6795.

[22]Y. Yılmaz, Ş.C. Genç, Z. Karacık, Ş. Altunkaynak, Two contrasting magmatic associations of NW Anatolia and their tectonic significance. J. Geodyn. 31 (2001) 243-271.

[23]M. Fytikas, O. Giulianni, F. Innocenti, P. Manetti, R. Mazzuoli, A. Peccerillo, L. Villari, Neogene volcanism of the Northern and Central Aegean region. Ann. Geol. Pays Hellen. 30 (1980) 106.

[24]Y. Y1lmaz, An apprroach to the origin of young volcanic rocks of Western Turkey. In A. M. C. Şengör (Editor), Tectonic evolution of the Tethyan Region. Kluwer Academic Publishers, vol. 259 (1989) $159-189$.

[25]Y. Y1lmaz, Comparison of young volcanic associations of western and eastern Anatolia formed under a compressional regime: a review. Jour. of Volc. and Geoth. Res. 44 (1990) 1-19. 
[26]Y. Savaşçın, N. Güleç, Neogene volcanism of western Anatolia-Field excursion B3. Int. Earth Sci. Congr. on Aegean Region. İzmir, Turkey. (1990).

[27]N. Akdeniz, N. Konak, Menderes Masifi'nin Simav dolaylndaki kaya birimleri, ve metabazik, metaultrabazik kayaların konumu, TJK Bülteni, 22 (1979) 175-184.

[28]M. Delaloye, E. Bingöl, Granitoids from Western and Northwestern Anatolia: Geochemistry and Modeling of Geodynamic Evolution. Int. Geol. Rev. 42 (2000) 241-268.

[29]A. Hasözbek, B. Erdoğan, M. Satır, Alaçam Dağları'nın Jeolojisi ve Alaçam Graniti'nin Jeolojik Konити (Balıkesir, Batı Anadolu), 62. Türkiye Jeoloji Kurultayı Bildiri Özleri, Ankara (2009).

[30]F. Erkul, S.T. Erkul, S.T. Geology of the Early Miocene Alacamdağ magmatic complex and implications for the western Anatolian extensional tectonics. Bulletin of the Mineral Research and Exploration Institute of Turkey (MTA) 141 (2010) 1-25.

[31]F. Erkül, C. Helvacı, H. Sözbilir, Evidence for two episodes of volcanism in the Bigadiç borate basin and tectonic implications for western Turkey. Geol. Jour. 47 (2005) 545-570.

[32]N. Konak, Simav dolayının jeolojisi ve metamorf kayaçlarının evrimi. İstanbul Yerbilimleri, 3 (1982) 313-337.

[33]T. Ercan, A. Dinçel, S. Metin, A. Türkecan, E. Günay, Uşak yöresindeki neojen havzaların jeolojisi. Türkiye Jeoloji Kurumu Bülteni, 21 (1978) 97-106.

[34]R.W. Le Maitre, A classification of igneous rocks and glossary of terms. Recommendations of the IUGS Commission on the systematics of Igneous rocks. Oxford: Black well (1989).

[35]T.N. Irvine, W.R.A. Baragar, A guide to the chemical classification of the common volcanic rocks. Can. J. Earth Sci. 8 (1971) 523-548.

[36]H.R. Rollinson, Using Gochemical Data: Evaluation, Pressentation, Interpretation. Longman Scientific\&Technical, New York (1992) 252.

[37]T. Koralay, İncesu İgnimbiritnin (Kayseri) jeolojisi, petrolojisi ve ayırtman özellikleri. Ankara Üniversitesi Fen Bilimleri Üniversitesi Enstitüsü, Ankara (2006).

[38]S. Sun, W.F. McDonough, Chemical isotopic systematic of oceanic basalts: implications for mantle compositions and processes. Magmatism in the Oceanic Basins, A.D. Saunders and M.J. Norry (eds) . J. Geol. Soc. London. 42 (1989) 313-345.

[39]J.A. Pearce, Role of the sub-continental lithosphere in magma genesis at active continental margins. Continental Basalts and Mantle Xenoliths, C.J. Hawkesworth and M.J. Norry (eds), Shiva, Cheshire (1983) 230-249.

[40]J.B. Gill, Orogenic Andesites and Plate Tectonics. Springer, Berlin (1981) 390 